\title{
NOVÁ ZJIŠTĚNÍ PRŮZKUMU ZAKÁZANÉ KRAJINY DOUPOVSKÝCH HOR - ZANIKLÉ STŘEDOVĚKÉ VESNICE
}

\author{
FILIP PREKOP - JIŘÍ CRKAL - DAVID ČERNÝ - PETR KRIŠTUF - VOJTĚCH PEKSA
}

\begin{abstract}
Abstrakt: Př́spěvek predstavuje devět nově lokalizovaných archeologických lokalit v Doupovských horách, v prostoru aktivního vojenského újezdu Hradiště, okres Karlovy Vary. Byly identifikovány pomoci archeologické interpretace antropomorfnich prvkü digitálního modelu reliéfu území újezdu. Ve všech prípadech se jedná o relikty sídelních areálů z počátků středověkého osidlování vyššich partii Doupovských hor. $V$ bezprostředni blizkosti tři vesnic se rozprostíraly i relikty opevněných sídel - tvrzišt’. Díky spolupráci Památkového ústavu, ú. o. p. v Lokti, se správou újezdu se na pěti z nich podařlo provést povrchový průzkum, během nějž bylo ověreno zminěné pozorování a ziskána pestrá škála vrcholně až pozdně středověké keramiky. Technologická variabilita keramiky odráži vztah k blizkým regionům Podbořanska a historického Loketska, čímž odpovidá tranzitnímu charakteru sledovaného území.
\end{abstract}

Kličová slova: Doupovské hory - zaniklé středověké vesnice-keramika-digitálni model reliéfu-tvrziště.

New findings of research into the forbidden territory of the Doupov Mountains-deserted medieval villages

Abstract: This contribution presents nine recently located archaeological sites in the Doupov Mountains (Doupovské hory), in the territory of the active military area of Hradiště, Karlovy Vary district. They were identified by means of the archaeological interpretation of anthropomorphic elements of a digital model of the territory's relief. All of them are the remains of settlement complexes from the period of the early medieval settlement of the elevated sections of the Doupov Mountains. In close proximity of three villages there were also the remains of fortified seats-manors. Thanks to the collaboration between the Heritage Institute in Loket and the military area administration it was possible to conduct surface collecting on five of these sites, which confirmed the mentioned observation and yielded a broad spectrum of pottery from the high and late Middle Ages. The technological variability of the pottery reflects links with the nearby historical regions Podboransko and Loketsko, and corresponds to the transit character of the territory.

Key words: Doupov Mountains - deserted medieval villages - pottery - digital model of landscape relief manor site.

\section{1 Úvod}

Doupovské hory, oddělující území dnešního Karlovarského a Ústeckého kraje, jsou z hlediska přírodního a historického vývoje unikátním regionem (obr. 1). Zdejší krajina byla díky své členitosti, druhu geologického podloží, ale především díky zrrízení vojenského újezdu počátkem 50. let 20. století (viz níže) uchráněna před výraznými transformacemi tolik typickými pro druhou polovinu 20. století. Vojenský výcvikový prostor je dodnes aktivně vojensky využívaným územím. Představuje tak obrovský potenciál pro poznání krajiny novověku, středověku a snad i pravěku z hlediska sídelní struktury a uspořádání zdejších komunitních areálů (k termínu Neustupný 1986; 2010). Nicméně nepřístupnost oblasti, která z ní utvořila „,zakázanou“ krajinu, značně komplikuje jakýkoliv archeologický výzkum. Ten se v takovém př́padě velmi podobá poznávání vzdálené planety, kdy jsou výzkumníci odkázáni pouze na snímky pořízené sondami, aniž by měli možnost místo navštívit. Otázkou, kterou si musíme logicky položit, je, zda archeologie vůbec dokáže za takových podmínek dospět k relevantním poznatkům. Podle našeho názoru a níže předložených výsledků se domníváme, že ano.

Předkládané výsledky našeho výzkumu krajiny Doupovských hor shrnují první poznatky, které se opírají o systematický průzkum digitálního modelu reliéfu celého území a v omezené míře též o povrchový průzkum. Přestože se již několik archeologů Doupovsku věnovalo, naše práce se jako první opírá o systematické vyhodnocování digitálního modelu reliéfu z dat leteckého laserového snímkování. Vzhledem k vysokému počtu a rozmanitosti našich zjištění 


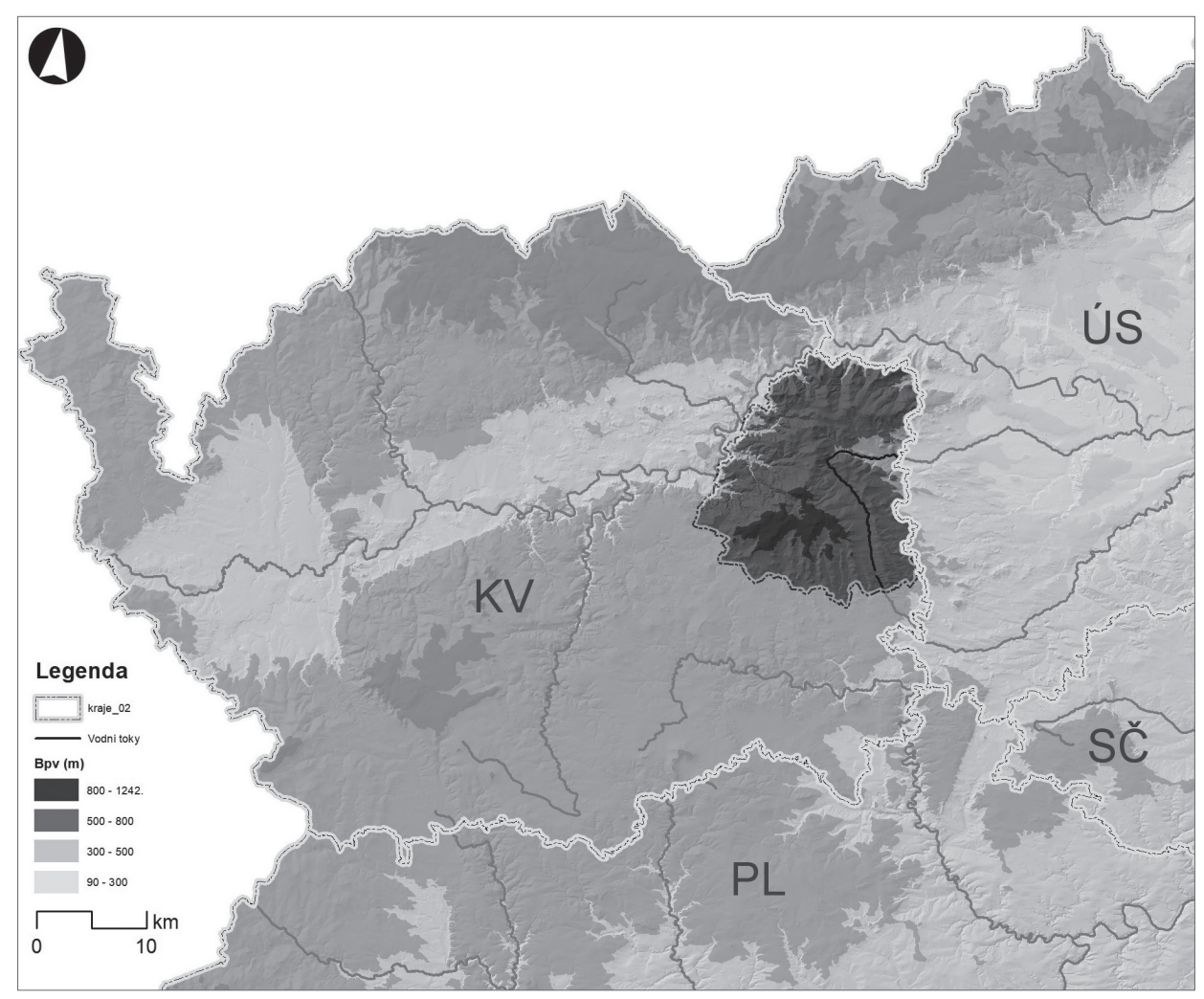

Obr. 1. Rozsah a reliéf území vojenského újezdu Hradiště ve vztahu k jeho okolí. Vyznačeny jsou hlavní vodní toky a vymezeny hranice krajů - Karlovarského (KV), Ústeckého (ÚS), Stř̌edočeského (SČ) a Plzeňského (PL). Autor F. Prekop, 24. 9. 2020.

Abb. 1. Gebietsumfang und - relief des Truppenübungsplatzes Hradiště in Bezug auf seine Umgebung. Gekennzeichnet sind die Hauptwasserläufe und die Grenzen der Regionen Karlsbad (KV), Aussig (ÚS), Mittelböhmen (SČ) und Pilsen (PL). Autor F. Prekop, 24. 9. 2020.

jsme zde přistoupili k představení jen určitého segmentu antropogenních objektů, kterými jsou lokalizované sídelní areály z vrcholného nebo pozdního středověku, jež nebyly zachyceny žádnými jinými mapovými díly druhé poloviny 18 . století až první poloviny 20 . století. Právě v této kategorii spatřujeme největší posun poznání, o které se zde chceme podělit. Věříme, že k dalším kategoriím archeologických památek se budeme moci vrátit v budoucích pracích.

\section{Metoda}

Rozsah a př́stupnost oblasti jasně determinují zvolenou metodologii. K území Doupovských hor lze v současné době jako k celku přistupovat pouze metodami dálkového průzkumu Země, přičemž některé metody této oblasti jsou navíc nevyužitelné. Nelze např́iklad pořizovat šikmé letecké snímky krajiny. Můžeme říci, že jsme odkázáni pouze na data získaná v rámci historických kampaní anebo projektů státní správy a armády. Vycházíme tedy z interpretace digitálního modelu reliéfu, ortofotomap oblasti, historických map a leteckých měřických snímků. Tyto metody jsou jediné dostupné pro studium nepřístupné krajiny jako celku a je obecně známo, že mají určité interpretační limity (Gojda 2004; 2017). Výrazným problémem je validace struktur zjištěných pomocí těchto metod. Č́stečně lze postupovat kombinací výše uvedených zdrojů. 
Např́iklad validovat struktury objevené na digitálním modelu reliéfu pomocí historických map. Tento postup je však použitelný spíše pro struktury novověkého stáří. Obecně je za ideální validační metodu považován terénní povrchový průzkum antropogenních tvarů reliéfu (Gojda 2017). Ten je ovšem v prostředí aktivního vojenského újezdu značně problematický.

Režim př́stupu do prostoru vojenského újezdu Hradiště neumožňuje při povrchovém průzkumu analytický postup. Některé oblasti jsou zcela nepř́stupné, některé jsou přístupné jen v určenou dobu a za doprovodu pracovníků správy vojenského újezdu (obr. 2). Proto musel být zvolen postup, který při terénních aktivitách respektoval tato pravidla. Fyzická návštěva vojenského újezdu se připravovala vždy ve spolupráci se správou Vojenského výcvikového újezdu

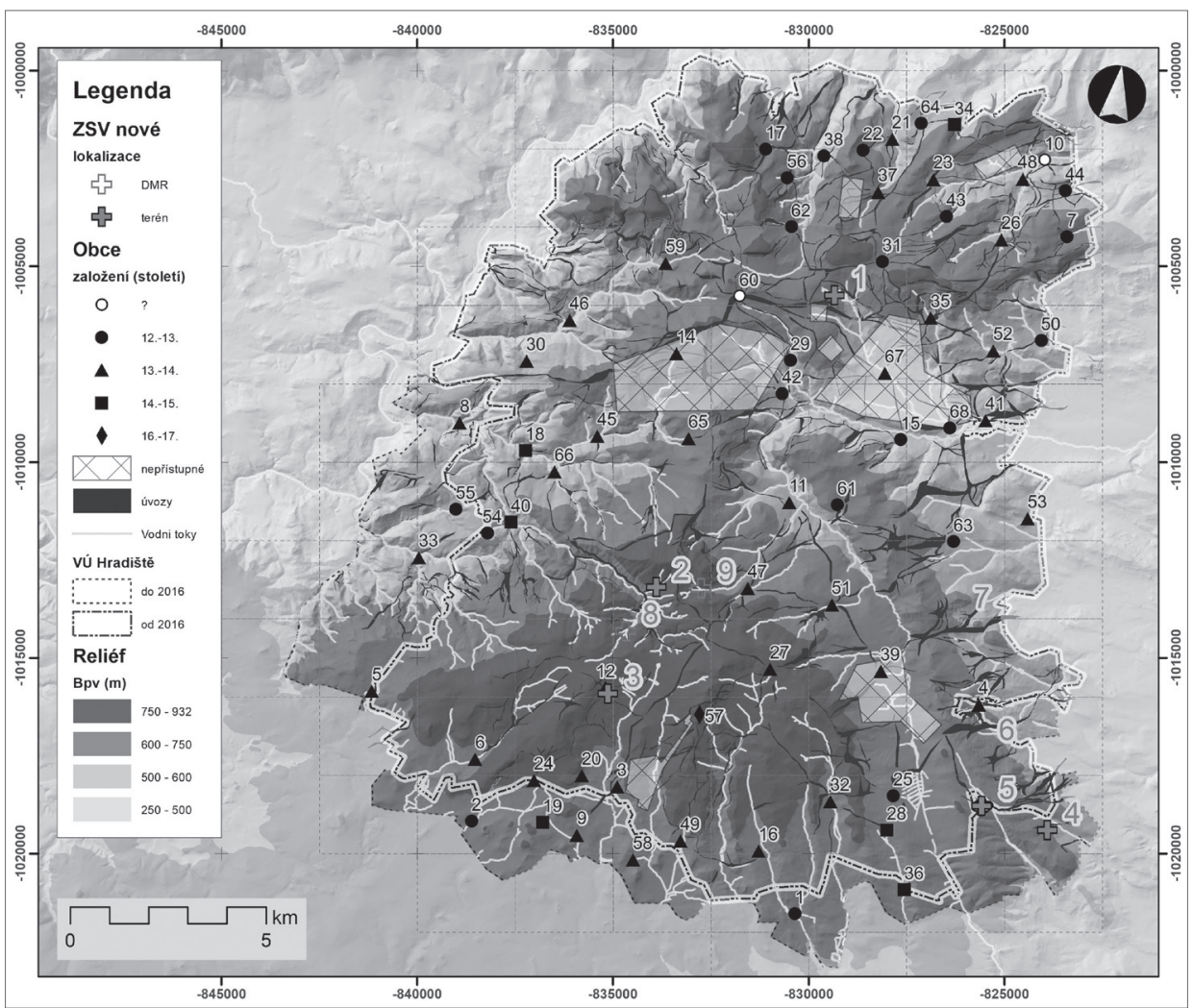

Obr. 2. Relikty osídlení Doupovska a rozsah území vojenského újezdu Hradiště. Šrafovaná plocha označuje trvale veřejnosti nepř́istupná území. Vyznačené jsou ověřené (terén) a předpokládané (LLS) lokalizace zaniklých středověkých osad Doupovska. Znázorněna jsou také ostatní známá sídla a pravděpodobná doba jejich založení. 1 - ZSV v poloze Ledviny s dvojicí tvrzišt'; 2 - ZSV v lokalitě Na pile s dvojitě opevněným tvrzištěm; 3 - ZSV s tvrzištěm při osadě Doupovské Mezilesí; 4 - ZSV Ořkov na Ořkovské louce, obec Valeč; 5 - ZSV na Mlýnském potoce, obec Valeč; 6 - ZSV pod vrchem Č́íhaná; 7 - ZSV Leskov; 8 - ZSV na Pstružném potoce, patrně s tvrzí; 9 - ZSV Krynles. Známé obce, zaniklé v letech 1953 a 1954 (tab. 1). Autor V. Peksa, 24. 9. 2020.

Abb. 2. Siedlungsrelikte der Region Duppau und Umfang des Truppenübungsplatzes Hradiště. Die schraffierte Fläche kennzeichnet für die Öffentlichkeit dauerhaft nicht zugängliche Gelände. Gekennzeichnet wurden verifizierte (Gelände) und mutmaßliche (Laserhöhenmessung) Lokalisierungen von mittelalterlichen Dorfsiedlungen der Region Duppau. Veranschaulicht wurden auch die übrigen bekannten Sitze und ihr wahrscheinlicher Gründungszeitraum. 1 - Mittelalterliche Dorfwüstung in der Lage Ledviny mit zwei Festungsstätten; 2 - Mittelalterliche Dorfwüstung an der Fundstelle Na pile mit doppelt befestigter Festungsstätte; 3 - Mittelalterliche Dorfwüstung mit Festungsstätte an der Siedlung Doupovské Mezilesí; 4 - Mittelalterliche Dorfwüstung Ořkov auf der Ořkover Wiese, Gemeinde Valeč; 5 - Mittelalterliche Dorfwüstung am Mühlenbach, Gemeinde Valeč; 6 - Mittelalterliche Dorfwüstung unterhalb des Hügels Číhaná; 7 - Mittelalterliche Dorfwüstung Leskov; 8 - Mittelalterliche Dorfwüstung am Bach Pstružný potok, offenbar mit Feste; 9 - Mittelalterliche Dorfwüstung Krynles. Bekannte Gemeinden, in den Jahren 1953 und 1954 verschwunden (Tab. 1). Autor V. Peksa, 24. 9. 2020. 
Hradiště a v intencích jí stanovených podmínek. Jmenovitě zde musíme poděkovat za opakovanou vstř́cnost vedení správy újezdu, prrednostovi Ing. Petru Vašíčkovi a paní Boleslavě Peroutkové. V terénu bylo možné dokumentovat jen předem zvolené lokality, které byly vytipovány na základě interpretace digitálního modelu terénu. Rovněž jsme se soustředili na období brzkého jara, kdy je nejnižší vegetační kryt. I tato podmínka vedla k tomu, že zkoumaný prostor mohl být navštíven maximálně jednou ročně ve dvoudenní kampani, což značně omezuje počet dokumentovaných lokalit.

Digitální model reliéfu se skládá z 89 listů SMO 5 pokrývajících celé území újezdu v původním rozsahu, tj. před rokem 2016. Data pořízená zeměměřickým a katastrálním úřadem jsme interpolovali algoritmem spline do pravidelného rozestupu měřených bodů o velikosti základní buňky 0,5 × 0,5 m. Digitální model reliéfu jsme zobrazili metodou Hillshade za použití Local relief model a Skyview factor. Zpracování modelu včetně jeho zobrazení probíhalo v softwarovém prostředí programu ArcGis 10.2 a Relief Visualization Toolbox, ver. 2.2.1. Vzhledem k rozsahu oblasti byly mapové listy zpracovány dávkově se shodně nastavenými parametry. Následně jsme pro objevené zájmové lokality zhotovili digitální modely s individuálním nastavením tak, aby co nejvíce vynikly reliéfní změny. Samotný terénní průzkum vybraných lokalit se skládal z fotodokumentace sledovaných objektů, povrchového sběru artefaktů v narušených částech perimetru a zaměření jejich nálezu pomocí GPS. Předložené výsledky pochází ze tří terénních kampaní v letech 2018-2020.

\section{Charakteristika Doupovských hor}

\subsection{Vojenský výcvikový újezd Hradiště}

Vojenský újezd Hradiště byl ustanoven usnesením vlády ke dni 1. února 1953 a je intenzivně využíván dodnes. Do ledna 2016 byl se svými 327 km² největším vojenským cvičištěm České republiky. V následujícím období bylo rozhodnuto o zmenšení území na západním a jižním okraji, čímž se rozloha ustálila na $280 \mathrm{~km}^{2}$. Hradiště je určeno k výcviku pozemního vojska, letectva a protivzdušné obrany, a to včetně užití ostrého střeliva, a nácviku vzájemné součinnosti těchto armád (Komár 1993, 79). Dělí se na pět dílčích katastrálních území: Doupov u Hradiště, Bražec u Hradiště, Radošov u Hradiště, Žd'ár u Hradiště a Tureč u Hradiště. Po uvedeném zmenšení došlo ke vzniku nových civilních obcí Doupovské Hradiště a Bražec, které nyní již nejsou pod vojenskou správou.

\subsection{Př́rodní podmínky}

Území vojenského újezdu Hradiště zaujímá centrální část morfologického útvaru Doupovské hory. Rozprostírá se $\mathrm{v}$ jejich centrální části s nejvyšším vrcholem Hradiště o výšce $933 \mathrm{~m} \mathrm{n}$. m. Z geologického hlediska se jedná o největší souvislý vulkanický celek v Českém masivu (Hradecký a kol. 2006, 22). Hlavní vulkanické centrum mělo charakter štítového vulkánu $\mathrm{s}$ velmi mírně ukloněnými svahy, který byl aktivní v období starších třetihor, přibližně před 23-34 mil. let (Hradecký a kol. 2016, 25). V období mladších třetihor se sopečná aktivita vázala již jen na dílčí vulkanická centra při obvodu masivu. V jistých lokalitách lze nalézt pozůstatky i starších prvohorních sladkovodních sedimentů, s četným výskytem různých fosilií, které byly vulkanickou aktivitou překryty až 500 m mocnou vrstvou (Lojka 2016, 19). V mladších obdobích formovala Doupovské hory již jen eroze. Půdy Doupovských hor tvoří téměř výhradně eubazické kambizemě. Jsou charakteristické svou bohatostí na živiny, ale zároveň jsou postižené hojným výskytem skeletu (kamení), který výrazně ztěžuje jejich hospodářské využití. Na druhé straně právě jemu vděčíme za dobrou čitelnost reliéfu krajiny. Množství skeletu bylo nutné před hospodařením z obdělávaných ploch odstranit, čímž se budovaly početné a výrazné mezní zídky, snosy kamení a podobně. Místní půdy jsou také ohrožené erozí, především jejich jemná složka. Přesto 
právě zemědělství bylo hlavním způsobem obživy zdejších obyvatel. Dominovalo ovocnářství, lukařství a pastvinářství (Janderková 2016, 111).

\subsection{Dějiny archeologického poznání}

Poznáváním archeologického dědictví Doupovska se nejvýrazněji zabýval Jiří Klsák. Koncem 80. let prováděl jednak terénní prospekci, jednak badatelské výzkumy několika lokalit. Nejrozsáhlejší prací byl výzkum hrádku v poloze Kostelní Horka, k. ú. Bražec, který J. Klsák prováděl v letech 1987-1989. Archeologické výzkumy realizoval také v níže zmíněném tvrzišti v poloze Na pile, pod vrchem Pustý zámek, tvrzišti na Kloboukovském vrchu u obce Maleš nebo hradu u Kotviny. Terénní aktivity a dosažená zjištění výstižně shrnul ve své bakalářské práci jeho tehdejší spolupracovník Petr Hereit (2000). Tato velmi kvalitní práce obsahuje i výčet všech známých archeologických lokalit Doupovska, včetně intravilánů obcí zaniklých v souvislosti se zřízením vojenského újezdu jako potenciálních archeologických lokalit. Odborným základem poznání kulturního bohatství a historie osídlení Doupovska tvoří dnes především práce Zdeny Binterové Zaniklé obce Doupovska I., II. (1998; 2004).

Č́stečně se oblasti dotýká také práce Antona Gnirse, který v roce 1933 mapoval památky okresu Karlovy Vary v rámci programu mapování památek a uměleckých předmětů České republiky. Bohužel práce vyšla, s přispěním jeho dcery, až o mnoho let později (1996). Obdobně jako pro jiné části území České republiky je základní charakteristika a lokalizace všech dosud známých archeologických lokalit Doupovska evidována v prostředí Státního archeologického seznamu, spravovaná Generálním pracovištěm Národního památkového ústavu (Státní archeologický seznam 2020). Zároveň byly do nové Archeologické mapy ČR revidovány údaje ze starší Archeologické databáze Čech spravované Archeologickým ústavem AV ČR, Praha, v. v. i.

\subsection{Specifika osídlení}

Osídlení Doupovských hor bylo po celou dobu značně dynamické. V poslední etapě své existence patřilo k řídce osídleným oblastem. Hustota osídlení v závěru 19. století a první polovině 20. století odpovídala 6-7 osobám na $\mathrm{km}^{2}$ a celkový počet obyvatel nepřesahoval 14500 . Největším sídlem bylo městečko Doupov s 1400 až 1500 obyvateli (tab. 1). Definitivní vysídlení všech obyvatel z oblasti vojenského prostoru proběhlo ve třech vlnách v průběhu let 1953 a 1954 (Binterová 1998; 2004).

Doklady pravěkého osídlení Doupovska jsou velmi skromné s minimem informací o jejich nálezových okolnostech. Charakteristický je soubor pěti neolitických kamenných broušených seker, u kterých je známé pouze katastrální území místa nálezu. Dále evidujeme dalších 23 eneolitických seker, nicméně bližší než katastrální určení je známé pouze u dvou z nich. Je to kamenný mlat z polohy Červený vrch u Doupova a sekerka ze svahu Jánského vrchu u Hluboké. Přesné nálezové okolnosti známe pouze u jediné kamenné sekyrky od Jánského vrchu u obce Hluboká, která pochází z naplavené humózní vrstvy, 50 m západně od vrcholu (Plesl-Hájek-Martínek 1983, 160). Za ojedinělé nálezy lze považovat dvojici halštatských náramků s nejistým prostorovým určením, snad z okolí Doupova (Hereit 2000, 143). Posledním potenciálním prehistorickým nálezem ze sledovaného území má být laténský střep silnostěnné nádoby z Jírova. Ten byl do sbírek Karlovarského muzea převzat z muzea v Doupově společně se středověkými nálezy. Bohužel není opatřen žádným bližším popiskem. Jeho vztah ke sledovanému území je tak značně nejistý (Plesl-Hájek-Martínek 1983, 43).

Hlavní prvky sídelní struktury Doupovska se začínají konstituovat od 12. století a další se rozvíjí v následujícím 13. století (Binterová 1998, 7; Velímský 1998, 69-80; 2002, 103-114). V mladším období pozdního středověku a raného novověku se zde projevovaly typické znaky periferních oblastí. Hlavním z nich byla citlivost na negativní výkyvy klimatických podmínek a také na projevy politicky nestabilních období. Známé jsou doklady plenění vesnic z období 
Tab. 1. Známé obce Doupovska a doba jejich založení s určeným druhem plužiny, dle písemných pramenů a projevu na digitálním modelu reliéfu. Autor V. Peksa, 24. 9. 2020.

Tab. 1. Bekannte Gemeinde Duppau und ihre Gründungszeit mit bestimmter Flurart gemäß den schriftlichen Quellen und ihrer Erscheinungsform im digitalen Reliefmodell. Autor V. Peksa, 24. 9. 2020.

\begin{tabular}{|c|c|c|c|c|c|c|}
\hline \multirow{2}{*}{$\begin{array}{l}\text { Ozn. } \\
\text { obce }\end{array}$} & \multicolumn{2}{|r|}{ Název } & \multicolumn{2}{|c|}{ Lokalizace } & \multirow{2}{*}{\begin{tabular}{|c|} 
Založení \\
století
\end{tabular}} & \multirow{2}{*}{ Druh plužiny } \\
\hline & česky & německy & E_WGS & N_WGS & & \\
\hline 1 & Albeřice & Alberitz & 13,1664 & 50,1648 & 12.-13. & záhumenicová klínová \\
\hline 2 & Bražec & Bergles & 13,0471 & 50,1744 & 12.-13. & záhumenicová klínová \\
\hline 3 & Březina & Pirk & 13,0966 & 50,1872 & 13.-14. & záhumenicová, trat'ová \\
\hline 4 & Bukovina & Buckwa & 13,2201 & 50,2186 & 13.-14. & radiální, trat’ová \\
\hline 5 & Činov & Shönau & 13,0046 & 50,2003 & 13.-14. & záhumenicová, tratová \\
\hline 6 & Dlouhá & Langgrün & 13,0449 & 50,1885 & 13.-14. & záhumenicová \\
\hline 7 & Dlouhý Luh & Langenau & 13,2257 & 50,3280 & 12.-13. & záhumenicová klínová, trat’ová \\
\hline 8 & Dolní Lomnice & Unter Lomitz & 13,0208 & 50,2642 & 13.-14. & úseková \\
\hline 9 & Dolní Valov & Unter Wohlau & 13,0850 & 50,1749 & 13.-14. & $?$ \\
\hline 10 & Donín & Dohnau & 13,2136 & 50,3446 & $?$ & $?$ \\
\hline 11 & Doupov & Duppau & 13,1420 & 50,2578 & 13.-14. & trat'ová \\
\hline 12 & $\begin{array}{l}\text { Doupovské } \\
\text { Mezilesí }\end{array}$ & Olitzhaus & 13,0872 & 50,2087 & 16.-17. & trat'ová \\
\hline 14 & Heřmanov & Hermersdorf & 13,0938 & 50,2876 & 13.-14. & záhumenicová, trat'ová \\
\hline 15 & Hluboká & Tiefenbach & 13,1779 & 50,2761 & 12.-13. & záhumenicová, tratová \\
\hline 16 & Holetice & Holeditz & 13,1502 & 50,1777 & 13.-14. & záhumenicová, trat'ová \\
\hline 17 & Hora & Horn & 13,1141 & 50,3372 & $12 .-13$. & záhumenicová, klínová \\
\hline 18 & Horní Lomnice & Ober Lomitz & 13,0456 & 50,2603 & 14. -15 . & úseková \\
\hline 19 & Horní Valov & Ober Wohlau & 13,0723 & 50,1766 & 14. -15 . & $?$ \\
\hline 20 & Hradiště & Höfen & 13,0835 & 50,1885 & 13.-14. & záhumenicová, trat'ová \\
\hline 21 & Hrzín & Grün & 13,1584 & 50,3439 & 13.-14. & záhumenicová, úseková \\
\hline 22 & Humnice & Humnitz & 13,1486 & 50,3405 & 12.-13. & záhumenicová, trat’ová, úseková \\
\hline 23 & Hůrka & Horkau & 13,1752 & 50,3362 & 13.-14. & záhumenicová, úseková \\
\hline 24 & Javorná & Ohorn & 13,0669 & 50,1857 & 13.-14. & trat'ová \\
\hline 25 & Jeseň & Gässing & 13,1947 & 50,1950 & 12.-13. & záhumenicová, radiální, tratová \\
\hline 26 & Jindřichov & Heiniersdorf & 13,2026 & 50,3249 & $13 .-14$. & záhumenicová, úseková \\
\hline 27 & Jírov & Jurau & 13,1443 & 50,2193 & 13.-14. & záhumenicová, tratová \\
\hline 28 & Kopáčov & Kopitschau & 13,1944 & 50,1870 & 14.-15. & trat'ová \\
\hline 29 & Kozlov & Koslau & 13,1346 & 50,2902 & 12.-13. & záhumenicová, klínová, úseková \\
\hline 30 & Lipoltov & Lappersdorf & 13,0410 & 50,2806 & 13.-14. & záhumenicová \\
\hline 31 & Litoltov & Liesen & 13,1617 & 50,3158 & 12.-13. & záhumenicová, klínová, úseková \\
\hline 32 & Lochotín & Lochotin & 13,1728 & 50,1914 & 13.-14. & záhumenicová, klínová, úseková \\
\hline 33 & Lučiny & Hartmannsgrün & 13,0139 & 50,2322 & 13.-14. & záhumenicová \\
\hline 34 & Malá Lesná & Klein Spinnelsdorf & 13,1797 & 50,3494 & $14 .-15$. & úseková, trat’ová \\
\hline 35 & Maleš & Mohlischen & 13,1819 & 50,3047 & 13.-14. & záhumenicová, úseková \\
\hline 36 & Malý Hlavákov & Kleinlubigau & 13,2038 & 50,1741 & 14.-15. & záhumenicová, trat'ová \\
\hline 37 & Martinov & Merzdorf & 13,1564 & 50,3314 & 13.-14. & záhumenicová, trat'ová \\
\hline 38 & Mělník & Melk & 13,1351 & 50,3378 & 12. -13 . & záhumenicová, klínová \\
\hline 39 & Mětikalov & Meckl & 13,1835 & 50,2228 & 13.-14. & záhumenicová, trat'ová \\
\hline 40 & Mlýnská & Mühldorf & 13,0446 & 50,2436 & 14. -15. & úseková \\
\hline 41 & Obrovice & Wobern & 13,2069 & 50,2833 & 13.-14. & záhumenicová, trat’ová \\
\hline
\end{tabular}




\begin{tabular}{|c|c|c|c|c|c|c|}
\hline \multirow{2}{*}{$\begin{array}{l}\text { Ozn. } \\
\text { obce }\end{array}$} & \multicolumn{2}{|r|}{ Název } & \multicolumn{2}{|c|}{ Lokalizace } & \multirow{2}{*}{$\begin{array}{c}\text { Založení } \\
\text { století }\end{array}$} & \multirow{2}{*}{ Druh plužiny } \\
\hline & česky & německy & E_WGS & N_WGS & & \\
\hline 42 & Oleška & Olleschau & 13,1334 & 50,2824 & 12.-13. & záhumenicová, trat’ová \\
\hline 43 & Ostré & Westrum & 13,1819 & 50,3284 & 12.-13. & záhumenicová, klínová, tratová \\
\hline 45 & Pastviny & Ranzengrün & 13,0703 & 50,2661 & 13.-14. & záhumenicová, úseková \\
\hline 44 & Pastviny & Weiden & 13,2226 & 50,3384 & 12.-13. & záhumenicová, klínová, úseková \\
\hline 46 & Petrov & Petersdorf & 13,0542 & 50,2914 & 13.-14. & $?$ \\
\hline 47 & Prachomety & Promuth & 13,1320 & 50,2369 & 13.-14. & záhumenicová, trat’ová \\
\hline 48 & Radnice & Redenitz & 13,2069 & 50,3394 & 13.-14. & tratová \\
\hline 49 & Radošov & Reschwitz & 13,1220 & 50,1772 & 13.-14. & záhumenicová, trat'ová \\
\hline 50 & Ratiboř & Rodbern & 13,2223 & 50,3035 & 12.-13. & záhumenicová, klínová, tratová \\
\hline 51 & Řednice & Rednitz & 13,1626 & 50,2361 & 13.-14. & záhumenicová, trat'ová \\
\hline 52 & Růžová & Rosengarten & 13,2059 & 50,2994 & 13.-14. & záhumenicová, úseková \\
\hline 53 & Sedlec & Zettlitz & 13,2272 & 50,2625 & 13.-14. & záhumenicová, trat’ová \\
\hline 54 & Stará Ves & Altdorf & 13,0368 & 50,2403 & 12.-13. & záhumenicová, klínová, úseková \\
\hline 55 & Svatobor & Zwetbau & 13,0242 & 50,2446 & $12 .-13$. & záhumenicová, úseková \\
\hline 56 & Telcov & Teltch & 13,1233 & 50,3315 & 12.-13. & záhumenicová, klínová, úseková \\
\hline 57 & Těš & Tesch & 13,1217 & 50,2066 & 16.-17. & hromadná, trat'ová \\
\hline 58 & Tis u Luk & Tiess & 13,1063 & 50,1712 & 13.-14. & záhumenicová, trat'ová \\
\hline 59 & Tocov & Totzau & 13,0850 & 50,3078 & 13.-14. & záhumenicová, úseková \\
\hline 60 & Třídomí & Dreihäuseln (Schmied) & 13,1129 & 50,3030 & $?$ & $?$ \\
\hline 61 & Trmová & Dürmaul & 13,1590 & 50,2591 & 12.-13. & záhumenicová, trat'ová \\
\hline 62 & Tunkov & Tunkau & 13,1275 & 50,3206 & 12.-13. & záhumenicová, klínová, úseková \\
\hline 63 & Tureč & Turtsch & 13,2023 & 50,2548 & 12.-13. & záhumenicová, tratová \\
\hline 64 & Velká Lesná & Gross Spinnelsdorf & 13,1678 & 50,3486 & $12 .-13$. & záhumenicová, klínová, tratová \\
\hline 65 & Víska & Dörfles & 13,1027 & 50,2688 & 13.-14. & záhumenicová, tratová \\
\hline 66 & Zakšov & Sachsengrün & 13,0571 & 50,2565 & 13.-14. & záhumenicová, úseková \\
\hline 67 & Žd’ár & Saar & 13,1686 & 50,2905 & $13 .-14$. & záhumenicová, trat'ová \\
\hline 68 & Žebletín & Sebeltitz & 13,1947 & 50,2805 & 12.-13. & trat’ová \\
\hline
\end{tabular}

husitských válek nebo třicetileté války, kdy zde dochází k zániku celých vesnic, viz dále. Rovněž absence rud drahých kovů ve vyvřelinovém masivu Doupovských hor bránila rozvinutí sofistikovanějších průmyslových provozů, které by alespoň částečně kompenzovaly obtíže spojené s živobytím v členitém terénu o relativně vysoké nadmořské výšce.

\section{Nově lokalizované zaniklé středověké vesnice}

Naše zjištění se týkají pozůstatků raných fází středověkého osídlení sledované oblasti. Celkově se nám podařilo nalézt doklady př́tomnosti devíti vrcholně až pozdně středověkých sídelních areálů, které nejsou zohledněny na mladších mapových dílech. Jejich přítomnost prozrazuje strukturovaná mezní sít', která je osově nebo centrálně souměrná. V několika případech ji doprovází také pozůstatky opevněného panského sídla. Můžeme tak důvodně předpokládat, že k zániku sídelních areálů došlo právě v některém z uvedených období sociálního neklidu pozdního stř̌edověku až raného středověku. Níže představujeme jak terénním výzkumem ověřené polohy, tak několik zatím neověřených situací s vysokou mírou pravděpodobnosti. Číslování lokalit odpovídá pořadí, ve kterém byly provedeny terénní revize, př́ípadně samotné objevení lokalit. 


\subsection{ZSV s dvojicí tvrzišt' v poloze Ledviny (býv. k. ú. Žd'ár)}

Poloha Ledviny označuje místo objevu dvojice oválných tvrzišt' a blízké zaniklé středověké osady (obr. 3). Zde je nutné uvést, že lokalitu poprvé navštívil a popsal ve svých denících Jiří Klsák, a to 28. listopadu 1987. Zjištění ale nebylo nikdy publikováno a o existenci záznamu jsme se dozvěděli až po našem „znovuobjevení“. Lokalita se nachází na bývalém katastru obce Žd'ár, na půli cesty k obci Tunkov. Obě jmenované zanikly až v roce 1953. Prostorově má poloha blíže k obci Litoltov, od níž je vzdálena 1,4 km jihozápadním směrem. Jedná se o oblast prameniště Žd'árského potoka a jeho bezejmenného pravobřežního přítoku na jižním svahu vrchu Lesná (kóta $812 \mathrm{~m}$ n. m.). Právě na hraně př́íkrého levého břehu bezejmenné vodoteče je možné rozeznat markantní relikty zaniklého sídla. Pomyslné středy obou ohrazených ploch odděluje vzdálenost ca $75 \mathrm{~m}$, ve směru jihovýchod-severozápad (obr. 4). Severozápadní tvrziště dosahuje pravidelného kruhového tvaru o vnějším poloměru $30 \mathrm{~m}$. Ten je na severní polovině zvýrazněn mírným valem. Kruhový př́kop dnes dosahuje hloubky $30 \mathrm{~cm}$. Vnitřní ohrazená plocha má poloměr $15 \mathrm{~m}$ beze stop dílčího členění. Jihovýchodní tvrzišsě je spíše oválného tvaru s orientací hlavní osy severovýchod-jihovýchod. Vnější rozměry tvrziště jsou $45 \times 25 \mathrm{~m}$. Na severovýchodním okraji rozeznáváme hlubší př́íkop, který na severovýchodně nebo jihozápadě není nijak patrný. Opět je rozpoznatelný na jihovýchodním okraji. Vnitřní plocha druhého tvrziště dosahuje rozměrů $20 \times 15 \mathrm{~m}$. Severozápadní třetina vnitřní ohrazené plochy je o ca 1,4 m vyvýšená. Relikty blízkého osídlení se projevují v podobě teras a identifikovaných kumulací vrcholně a pozdně středověké keramiky. Více je

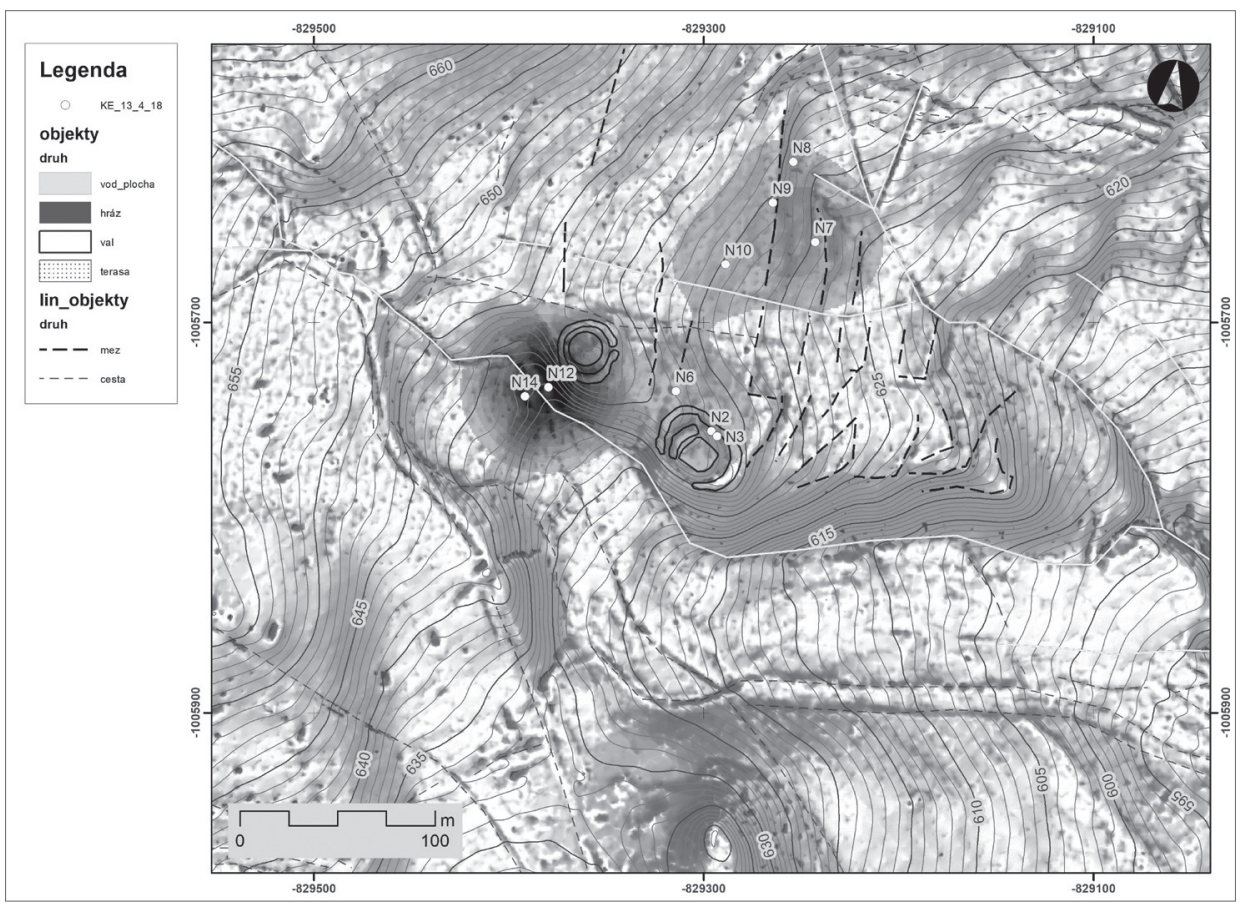

Obr. 3. Plán polohy Ledviny (1) vytvořený v digitálním modelu reliéfu a terénní prospekce. Zdůrazněny jsou relikty dvou tvrzišt', plužiny vsi a identifikovaná místa výskytů stř̌edověké keramiky. Černě jsou zdủrazněny početní kumulace nálezů. Autor F. Prekop, 24. 9. 2020.

Abb. 3. Im digitalen Reliefmodell erstellter Plan der Lage Ledviny (1) und Geländeprospektion. Hervorgehoben wurden die Relikte zweier Festungsstätten, die Dorffluren und die identifizierten Stellen mit Vorkommen mittelalterlicher Keramik. Schwarz hervorgehoben wurden die zahlreichen Fundhäufungen. Autor F. Prekop, 24. 9. 2020. 


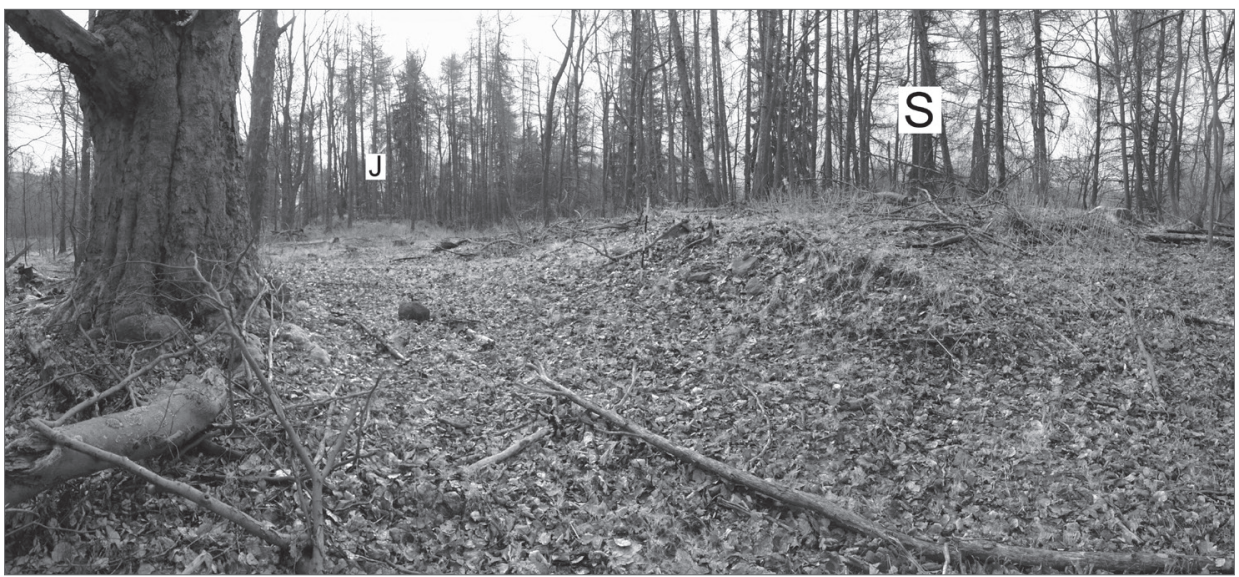

Obr. 4. Poloha Ledviny, pohled na dvojici tvrzišt' od severu k východu. V popředí patrné tvrziště se severním okrajem částečně porušeným mladší komunikací. Foto F. Prekop, 14. 4. 2018.

Abb. 4. Lage Ledviny, Blick auf die zwei Festungsstätten von Nord nach Ost. Im Vordergrund sichtbar die Festungsstätte mit durch den nördlichen Rand teilweiste verletztem jüngeren Weg. Foto F. Prekop, 14. 4. 2018.

dochovaná středověká parcelace severně od tvrzišt' v mírném svahu vrchu Lesná. Rozeznat místa jednotlivých usedlostí je zde však obtížné.

Při terénní revizi dne 13. dubna 2018 jsme získali soubor přibližně 30 keramických fragmentů z období vrcholného středověku s 15 typickými fragmenty (obr. 12:1). Všechny zdobené fragmenty nesly motiv ryté šroubovice. Nástřepí bylo světle hnědé, ale také šedivě bílé s hrubým ostřivem. Ojediněle byly zastoupeny fragmenty tmavě hnědočerné barvy s výraznou příměsí. Prostorová distribuce zachycených nálezů není zcela rovnoměrná. Představenou středověkou keramiku jsme nalezli na jihovýchodním tvrzišti a severně od obou. Výraznou kumulaci nálezů jsme zachytili v řečišti bezejmenné vodoteče, pod severozápadním tvrzištěm (obr. 3, poloha N12).

Překvapivě se nám nedostává písemných pramenů, které bychom mohli jednoznačně s touto lokalitou spojit. V širším okolí (mezi Žd'árem a Vintířovem) je jednou z mála známých zaniklých vsí původní Litoltov. Ves, která nesla název Litoltov do 50. let 20. století, byla původně ves Lysá neboli Liesen s první písemnou zmínkou až z roku 1454. Název Litoltov jí přisoudil nesprávně až J. Palacký. V písemných pramenech se původní zaniklý Litoltov objevuje pouze v letech 1411 a 1447 (Bernau 1881, 342; Profous 1949, 640-641), následně ze záznamů mizí. Vyloučit nelze ani příslušnost naší lokality k tzv. Maštovskému újezdu. Řazení jmenovaných vsí a dvorů v listině z roku 1196 není náhodné a lokality vytvářejí kompaktní celek (Velímský 1998, 69-80). Logicky by do sledované oblasti spadalo umístění Tulchowa. Ten se většinou ztotožňuje s Tunkovem nebo Telcovem, ač jsou obě vsi vysunuty výrazně k severu a kompaktnost ,újezdu“ narušují. Nelze vyloučit ani dále jmenovaný Bluvačov. Obě dvě vsi se ale objevují v písemném svědectví pouze a jen ve zmíněném roce 1196. Neznáme zde ani žádnou osobu s predikátem, ke které bychom mohli dvojici tvrzišt' přiřadit.

\subsection{ZSV v poloze Na pile (býv. $k$. ú. Jírov a Zakšov)}

Termínem označujeme sídelní areál, který se skládal z panského sídla, středověké vsi, mlýna a osamoceně stojící usedlosti. Zatímco tvrziště je relativně známé a prohlášené za kulturní památku, související ves a její plužina byly indikovány až pomocí našeho výzkumu. Parcely jednotlivých usedlostí se rozprostíraly na jižním svahu hřbetu Pustého zámku, při obou březích pravostranného přítoku Pstružného potoka (obr. 5, 6). Osada stála přibližně 4 km jihozápadně od bývalého Doupova, na hranicích historických katastrů obcí Jírov a Zakšov. Majitelem zdejších 


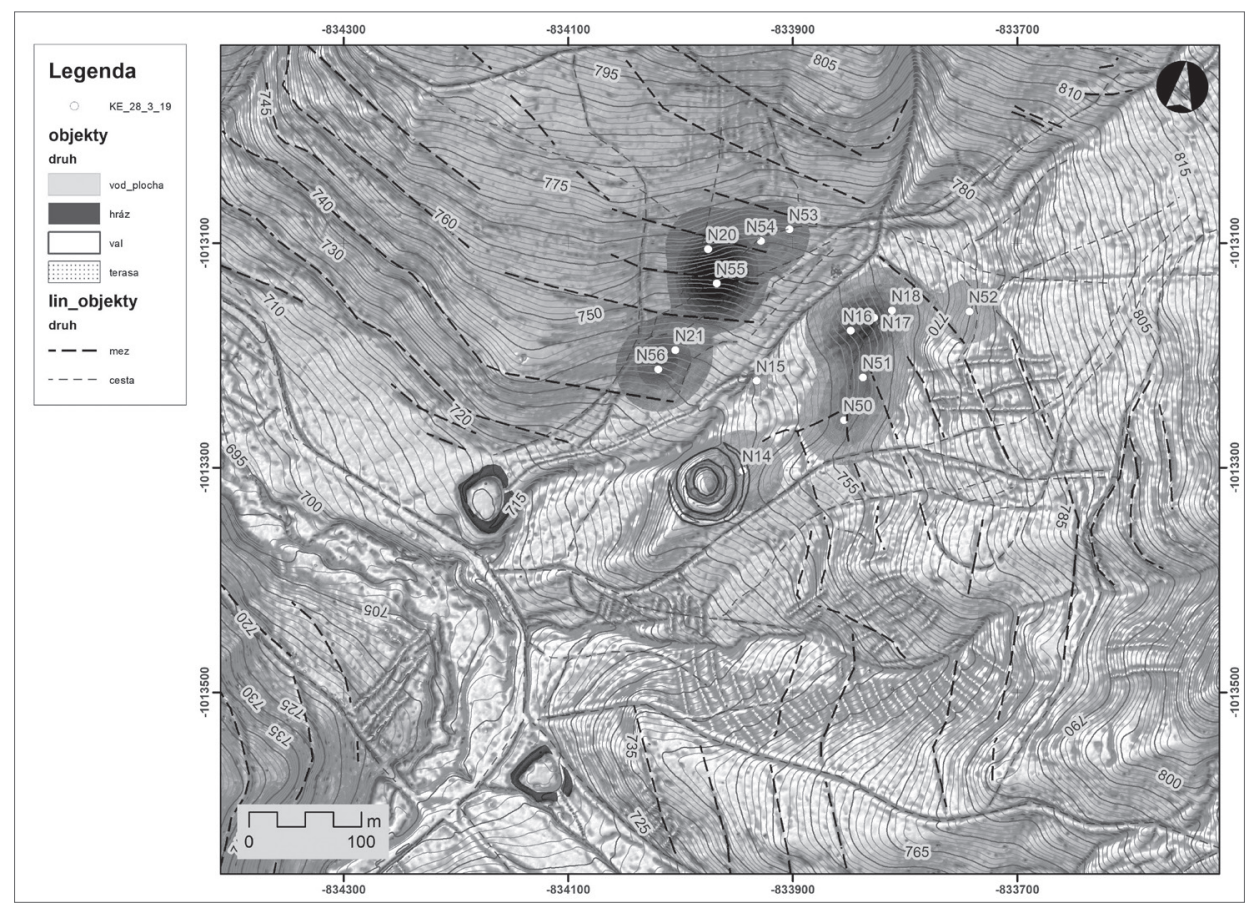

Obr. 5. Plán lokality Na pile vytvořený z dat digitálního modelu reliéfu a terénní prospekce. Objevená zaniklá středověká vesnice přiléhá k tvrzišti s dvojitou linií opevnění, které je známou archeologickou lokalitou, zkoumanou J. Klsákem koncem 80. let 20. století. Autor F. Prekop, 24. 9. 2020.

Abb. 5. Anhand der Daten des digitalen Reliefmodells erstellter Plan der Fundstelle Na pile und Geländeprospektion. Die entdeckte mittelalterliche Dorfwüstung grenzt an die Festungsstätte mit doppelter Befestigungslinie, bei der es sich um eine bekannte, von J. Klsák Ende der achtziger Jahre des 20. Jahrhunderts untersuchte Fundstelle handelt. Autor F. Prekop, 24. 9. 2020.

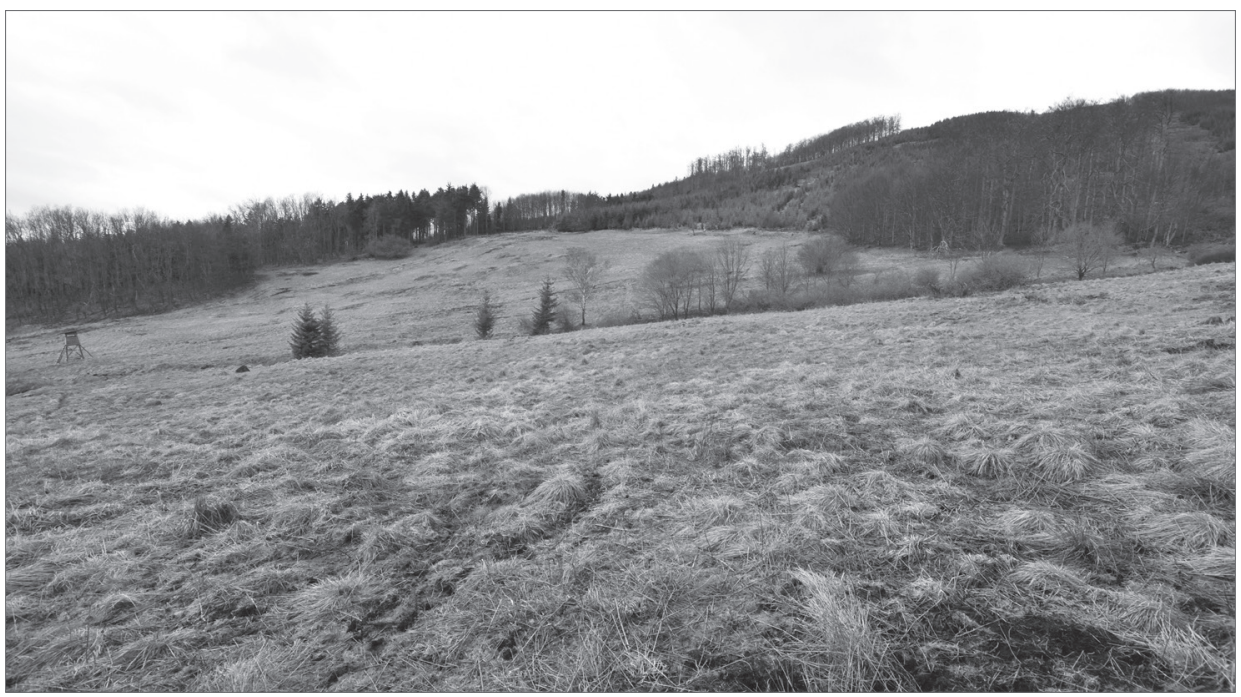

Obr. 6. Pohled na plochu návsi zaniklé vsi, k vrcholu Pustý Zámek, pohled od jihovýchodního okraje k severu. Foto F. Prekop, 28. 3. 2019.

Abb. 6. Blick auf die Fläche des Dorfpatzes der Dorfwüstung, in Richtung Hügel Pustý Zámek, Blick vom südöstlichen Rand nach Norden. Foto F. Prekop, 28. 3. 2019. 
pozemků býval držitel panství Doupov. Dispozičně se jednalo o dvouřadou dlouhou lesní lánovou ves s lineární plužinou a jihozápadní expozicí. Relikty zaniklých plužin ve formě mezních stupňů stoupají od 700 do $910 \mathrm{~m}$ n. m. a jsou patrné ve vzdálenosti $500 \mathrm{~m}$ severozápadně a $750 \mathrm{~m}$ jižně od vodoteče, která tvoří její osu. Relikty původních domovních parcel dochované ve formě svahových odřezů dosahují až k výšce $820 \mathrm{~m} \mathrm{n}$. m. Počet usedlostí lze odhadnout na 10-14. Na části plužiny jsou dosud částečně obhospodařované louky a recentní rybníček, zbytek dnes pokrývá vzrostlý les. Vodní náhon při Pstružném potoce na jižním okraji ZSV indikuje dále existenci mlýna. Na terase nad Pstružným potokem 0,6 km jižně od ZSV se nachází osamocený svahový zářez s kamennou destrukcí obklopený zaniklou plužinou. Patrně se zde nacházela osamocená usedlost. Podle I. vojenského mapování se v dolní části vsi nacházel dřevěný seník (pozemková parcela č. 65; Heu Langwiesschuppe). Z otisků stabilního katastru je o něco níže patrné místo Parní pily (Adelen Dampfbrettsäge), po které dostala poloha své aktuální označení (otisky stabilního katastru 2020). Pila však byla postavena až roku 1842 a po roce 1945 postupně zanikla.

Velmi výrazný objekt tvrziště se nachází v dolní části ZSV, na katastru Jírova (obr. 7). Sem jej správně řadí Petr Hereit $(2000,153)$, zatímco ve starší literatuře bývá spojováno s obcí Mlýnská. Jeho existenci zmiňují již Anton Gnirs nebo August Sedláček (Sedláček 1998, 247; Binterová 1998, 57; 2004, 57). Charakteristické opevnění tvoří dvojice koncentrických prŕikopů a valu obepínající jádro o průměru necelých $17 \mathrm{~m}$. Relativně rozsáhlý archeologický výzkum zde v roce 1987 prováděl Jiří Klsák, který se soustředil na poznání vývoje opevněné plochy. Hlavní sondou o velikosti $18 \times 0,5 \mathrm{~m}$ protnul celou ohrazenou plošinu. O tři roky později doplnil tři sondy o rozměrech $0,6 \times 0,6 \mathrm{~m}$. Bohužel nenalezl žádné stopy zástavby a jen minimum movitých nálezů. Z výzkumu pochází pouze 37 střepů, z čehož jen čtyři byly typické. Existenci celé stavby autor výzkumu zasazuje do 14. století (Hereit 2000,153). Během našeho povrchového průzkumu byl prokázán výskyt středověké keramiky v celém intravilánu vsi. Podařilo se získat

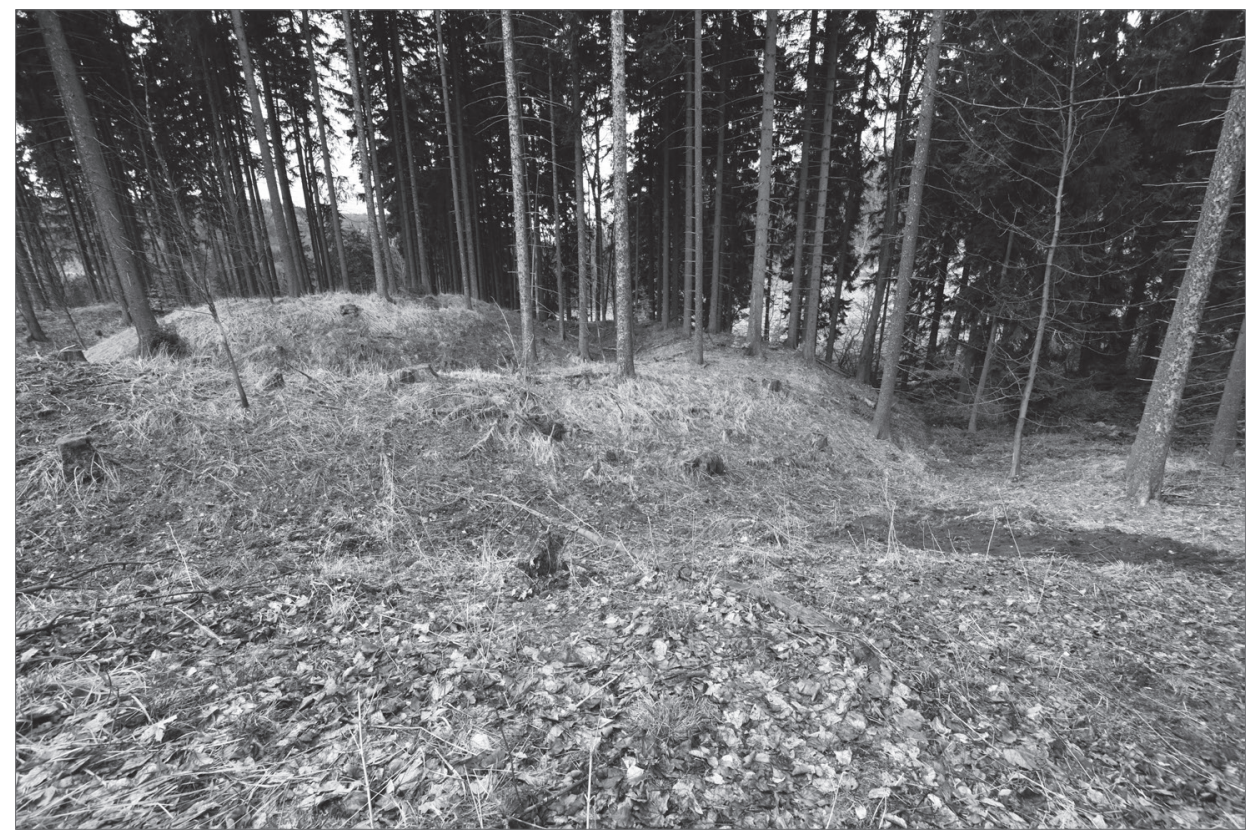

Obr. 7. Tvrziště lokality Na pile (2) s charakteristickým dvojitým koncentrickým opevněním, které je kulturní památkou. Severně od ní byla námi nalezena zaniklá stř̌edověká vesnice. Foto F. Prekop, 28. 3. 2019.

Abb. 7. Festungsstätte der Fundstelle Na pile (2) mit charakteristischer doppelter konzentrischer Befestigung, die ein Kulturdenkmal ist. Nördlich davon wurde von uns die mittelalterliche Dorfwüstung entdeckt. Foto F. Prekop, 28. 3. 2019. 
101 keramických fragmentů, z nichž bylo 33 typických. Některé z nich je možné řadit již do druhé poloviny 13. století, přestože většina opět odpovídá spíše 14. století. Fragmenty redukčního výpalu a s výraznou př́měsí slídy se nacházely v místech označených jako N18 a N52 v severovýchodní části intravilánu (obr. 5). Relativně často, v pěti různých polohách, jsme našli fragmenty jinak na Karlovarsku vzácně se vyskytující keramiky šedobílého nástřepí odpovídající produkci středního Poohří (obr. 12:2, N55_6, N56_1).

Bezesporu zajímavým nálezem je fragment drobné plastiky torza postavy o rozměrech $5,5 \mathrm{~cm} \times 3,0 \mathrm{~cm}$, která byla nalezena při průzkumu na jedné z teras nedaleko tvrziště (obr. 5 , poloha N50). Předmět zobrazuje postavu v dlouhém oděvu s náznakem drapérie (obr. 8). Profil je velmi mírně oválný. Jedna ze stran nese oválnou, vzhůru se rozšiřující stopu vystupující profilace, která může naznačovat vlasy nebo kápi. Osou plastiky prochází otvor, který se, stejně jako celkový průměr předmětu zužuje, a to od $1,5 \mathrm{~cm}$ do $1 \mathrm{~cm}$. Téměř identický artefakt pochází z blízkosti obytné věže hradu v Bečově nad Teplou, kde jej doprovázelo hned několik dalších drobných keramických plastik (Prekop 2017). Vedle městského a hradního prostředí se nalézají také i na hornických sídlištích, např́iklad v Kremsigeru (Derner 2018), nebo v prostředí poddanských vesnic, uved’me např́iklad Bystřec nebo Mstěnice (Belcredi 2006; Nekuda 1985). Na základě uvedeného kontextu předmět řadíme do druhé poloviny 14. století. Objasnění funkce drobné hrnčířské plastiky stále osciluje mezi dětskou (?) hračkou nebo votivní soškou. Zdá se, že toto dlouholeté tápání ukončila V. Hoffmannová (1996, 133), která nevylučuje ani jednu z těchto interpretací, naopak obě spolu mohou souviset (Měchurová 2010, 102).

Problematickou otázkou zůstává ztotožnění vsi s konkrétní lokalitou. Tvrziště i ZSV byla reflektována ve dvou sousedních vsích, v Jírově a Prachometech. Sommer $(1847,151)$ uvádí: „(...) dále opodál kostela sv. Vojtěcha $v$ tom samém lese zbytky hradu a na Hossagrün Wiese stopy více domu a jednoho mlýna." Ve stejném duchu informuje i Bernau (1896, 207), který ale navíc přidává: „(...) dle starých pamětí stávala v těchto mistech osada Bezděkov, která bezpochyby

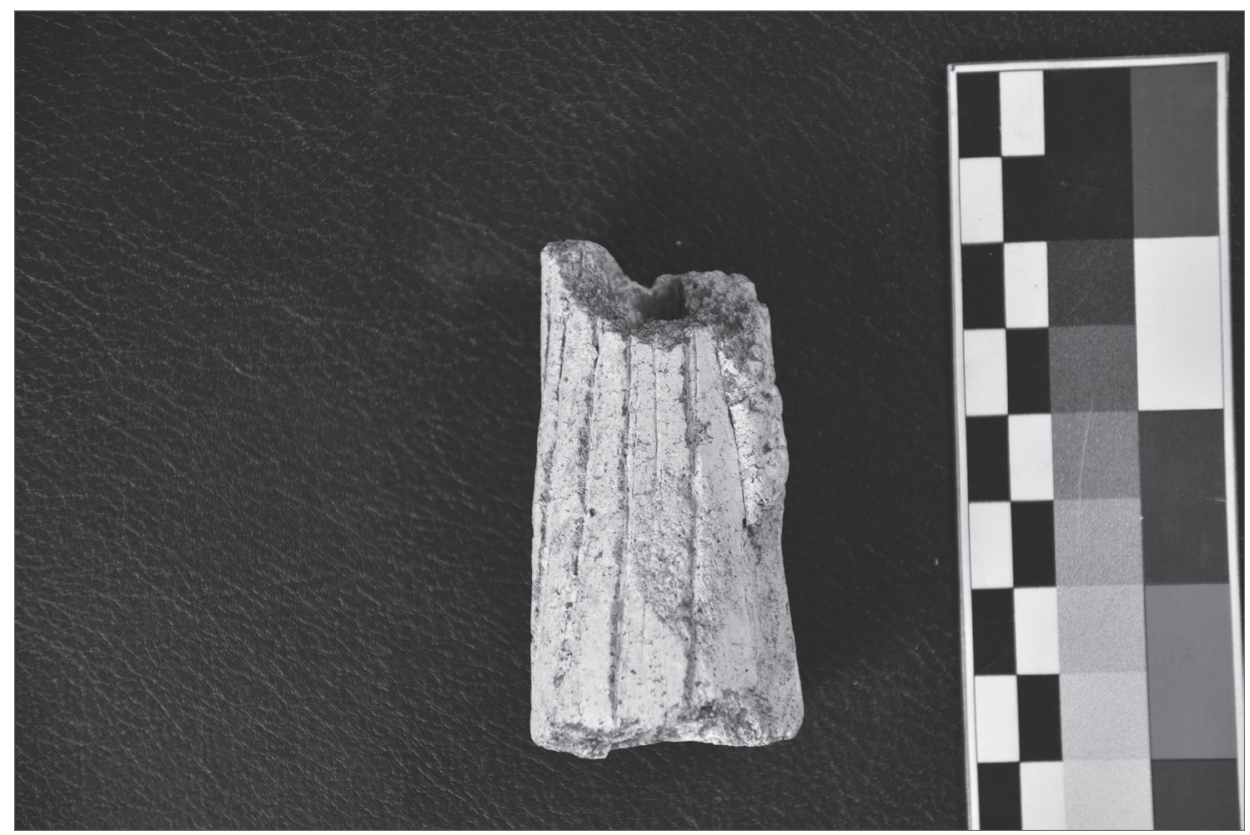

Obr. 8. Torzo drobné plastiky z 2. poloviny 14. století, z polohy N50, lokality Na pile (2). Autor J. Crkal, 28.3 .2019$.

Abb. 8. Torso einer Kleinplastik aus der 2. Hälfte des 14. Jahrhunderts, Lage N50, Fundstelle Na pile (2). Autor J. Crkal, 28. 3. 2019. 
tehdy úplné došla zkázy, když v prvnich dnech záři r. 1421 křižáci tudy od Žlutic hrnuli se k Maštovu. "Prachomety zase měli založit až ve třicetileté válce obyvatelé stále přepadávané vsi Unruh. Ty ale mají první písemnou zmínku v roce 1410. Langhans $(1986,3)$ uvádí: „(...) ve smèru k Parní pile obývali lidé osadu Hossagrün a dále na Dunkelsberg domy vsi Unruh. Tu ničili různí procházejicí, predevším Švédové za 30leté války, proto obyvatelé odešli. Několik přesídlenců odešlo do Öbere Gässe v Doupově, a větši díl založil Prachomety. V doupovském muzeu se ještě nacházeji nalezené švédské podkovy, meče a pistole." Zaniklá osada Bezděkov je lokalizována 2,5 km severně od ZSV Na pile. Osada Hossagrün je ztotožnitelná s lokalitou na Pstružném potoce. Toponymum Unruhe neboli Neklid při severovýchodním okraji uvádí pouze II. vojenské mapování; a ves tohoto jména není uvedena v žádném výčtu majetků doupovského panství. Zbývají osady zaniklé před rokem 1518 - Vrany a Strkbiceny, a roku 1518, respektive 1546 ještě existující Vous/Wauss (waussu... vesnice při dílu panství Doupov; DZ 7, fol. J 22v-23). Stupeň dochování a nálezy časně novověké keramiky v ZSV Na pile svědčí o pozdějším zániku vsi, zda ji můžeme spojit s uvedenými lokalitami, zůstává však zatím nezodpovězenou otázkou.

\subsection{ZSV Bernardsgrün (?) při Doupovském Mezilesí (býv. k. ú. Doupovské Mezilesí)}

K revizi jižního okraje intravilánu obce Doupovské Mezilesí nás přivedl odraz kruhové žlabovité deprese na pořízeném digitálním modelu reliéfu (obr. 9-10). Tato velmi drobná obec s méně než desítkou budov se rozprostírala okolo ústřední cesty přibližně 7 km severovýchodně od Bochova

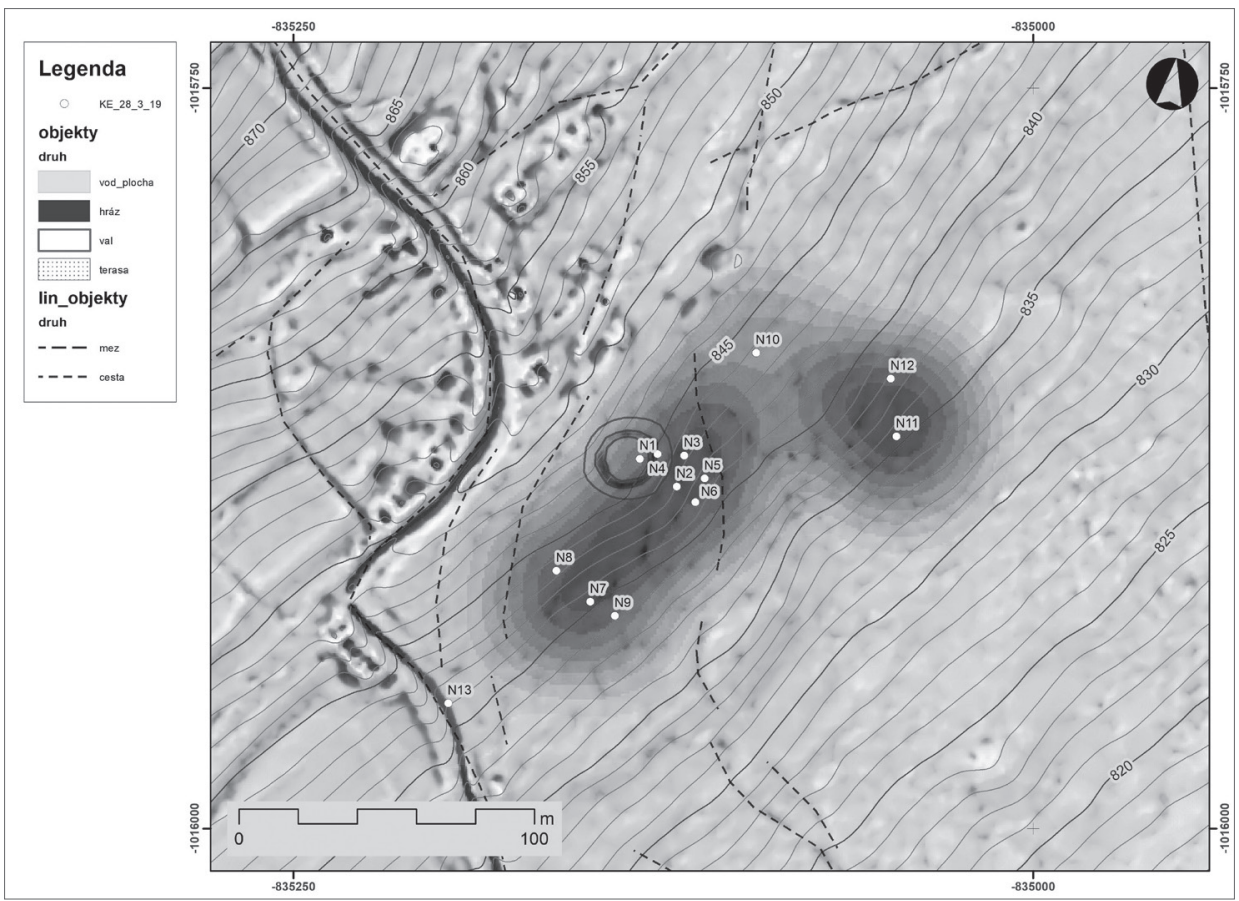

Obr. 9. Plán lokality Doupovské Mezilesí vytvořený z dat digitálního modelu reliéfu a terénní prospekce. Patrné relikty doposud neznámého tvrziště doprovázel výskyt vrcholně středověké keramiky, která odkazuje na existenci staršího předchůdce osady, která se velmi pravděpodobně rozprostírala níže po svahu, naproti nalezenému tvrzišti. Foto F. Prekop, 28. 3. 2019.

Abb. 9. Anhand der Daten des digitalen Reliefmodells erstellter Plan der Fundstelle Doupovské Mezilesí und Geländeprospektion. Die erkennbaren Relikte einer bislang unbekannten Festungsstätte wurden vom Vorkommen hochmittelalterlicher Keramik begleitet, die auf die Existenz eines Vorgängers der Siedlung hindeutet, die sich sehr wahrscheinlich gegenüber der entdeckten Festungsstätte tiefer den Hang hinunter erstreckte. Foto F. Prekop, 28. 3. 2019. 


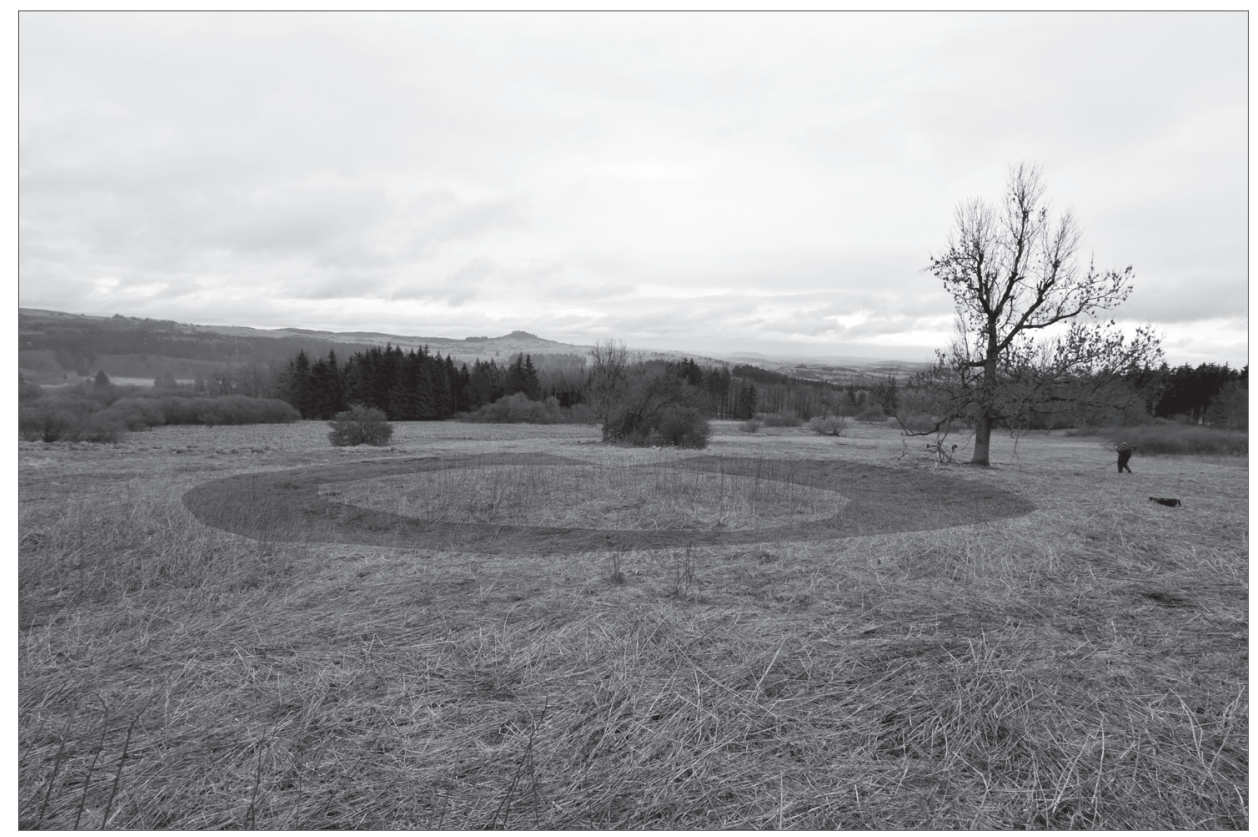

Obr. 10. Pohled na tvrziště u Doupovského Mezilesí, pohled k jihu. Plocha příkopu tvrziště je dodatečně graficky zdůrazněná. Foto F. Prekop, 28. 3. 2019.

Abb. 10. Blick auf die Festungsstätte an der Fundstelle Doupovské Mezilesí, Blick von Süden. Die Fläche des Grabens der Festungsstätte wurde zusätzlich grafisch hervorgehoben. Foto F. Prekop 28. 3. 2019.

a 6,7 km od Doupova. Od ústřední pravoúhlé zatáčky hlavní komunikace je nově identifikovaný objekt vzdálen ca $50 \mathrm{~m}$ VJV směrem. Jeho průměr je téměř kruhového tvaru s průměrem $25 \mathrm{~m}$ při vnějším okraji (obr. 9). Vnitřní plocha má průměr $14 \mathrm{~m}$. Hloubka reliktu př́ikopu nepřesahuje $0,5 \mathrm{~m}$. V okolí tvrziště jsme nezpozorovali relikty středověké plužiny ani při studiu digitálního modelu reliéfu.

Terénní revize místa proběhla 28. března 2019. Potvrdil se předpoklad, že se jedná o relikt stavby s kruhovým př́ikopovým ohrazením. V ploše tvrziště i v jeho okolí se podařilo nalézt fragmenty vrcholně a pozdně středověké keramiky. Celkem bylo nalezeno 69 fragmentů, z toho bylo typických dvanáct kusů. Motivem výzdoby devíti kusů byla mělká šroubovice (obr. 12:3). Materiál byl různě intenzivně slídnatý, nejvíce v místech N7 a N12. Několik fragmentů bylo zhotoveno z jemně plaveného těsta, s oxidačním výpalem. Datačně řadíme materiál do druhé poloviny 13. až do 15. století, s tím, že několik fragmentů může patřit až do první poloviny 16. století.

Celkovou situaci interpretujeme jako relikt starší fáze sídelního areálu, který se známým Doupovským Mezilesím souvisí jen velmi volně. Mohlo by jít o Bernardsgrün zmiňovaný roku 1411 jako pustý (RT II, 84), kdy byl prodáván spolu s Dlouhou (Langgrünn, 3 km JZ). Doupovské Mezilesí je až poválečný název, původně se vsi česky říkalo Olíčov, z německého Olitzhaus. Dle písemných pramenů je ves velmi mladého založení. První písemná zmínka je až z roku 1720 (Profous 1951, 271-272) a i samotný půdorys vsi naznačuje její mladší původ či přebudování. To rovněž naznačuje zmínka z roku 1580, kterou uvedla Z. Binterová $(1998,26)$. Hovoří o existenci panské myslivny, která se mohla stát základem vzniku budoucí osady. Poloha tvrziště, stejně jako distribuce keramiky na svahu pod vsí napovídá, že Doupovské Mezilesí vzniklo na místě starší zaniklé středověké vsi, která byla původně situována níže po svahu. Ves Doupovské Mezilesí, či správně Olitzhaus, vznikla tedy až v novověku, a to bez prrímé návaznosti na starší situaci. Spojení středověké vsi s Bernardsgrünem je pouze teoretické a není možné jej ověřit. Samotný název ale 
plně zapadá do skupiny názvů kolonizačních vsí v jejím bezprostředním okolí. Ty náležely do tzv. Šemnického újezdu zmiňovaného k roku 1239 (Velímský 2002, 114-115).

\subsection{ZSV Ořkov (k. ú. Valeč u Hradiště)}

Na katastru Valeč u Hradiště, obce Valeč, jsme nalezli relikty dvou zaniklých vsí. Území spadá do části, o kterou se zmenšil vojenský újezd v roce 2016 (obr. 2, lokality 4 a 5). První z nich se rozprostírala $\mathrm{v}$ dílčím údolí severovýchodního svahu Jedliny, ca $2 \mathrm{~km}$ severně od obce Valeč a $1 \mathrm{~km}$ severozápadně od samoty Ořkov, proti proudu Vrbičského potoka, v místě zvaném Ořkovská louka (obr. 11). Podle tvaru plužiny vsi se domníváme, že se jednalo o typ vsi s návesním půdorysem a záhumenicovou radiální plužinou, jež zčásti kopírovala vrstevnice svahu Jedliny. Náves osady zaujímala výškový interval 595 až $617 \mathrm{~m} \mathrm{n}$. m. V okolí lze identifikovat i další doplňkové tratě. Velikost vsi lze odhadovat na 8-12 usedlostí.

Terénní revize místa proběhla 13. března 2020. Přinesla celkem 29 keramických fragmentů. Přestože tento soubor nemůžeme považovat za zcela reprezentativní, je patrné, že i zde dominuje slídnatá a šedivě bílá keramická produkce. Z devíti typických fragmentů převládají pozůstatky plecí nádob zdobených šroubovicemi nebo výraznými či méně výraznými jednoduchými vodorovnými žlábky (obr. 12:4). Blíže datovatelný okraj nádoby je nepravé okruží z přelomu 14. a 15. století z šedobílé hmoty s výraznou příměsí ostřiva (obr. 12:4, V10_1).

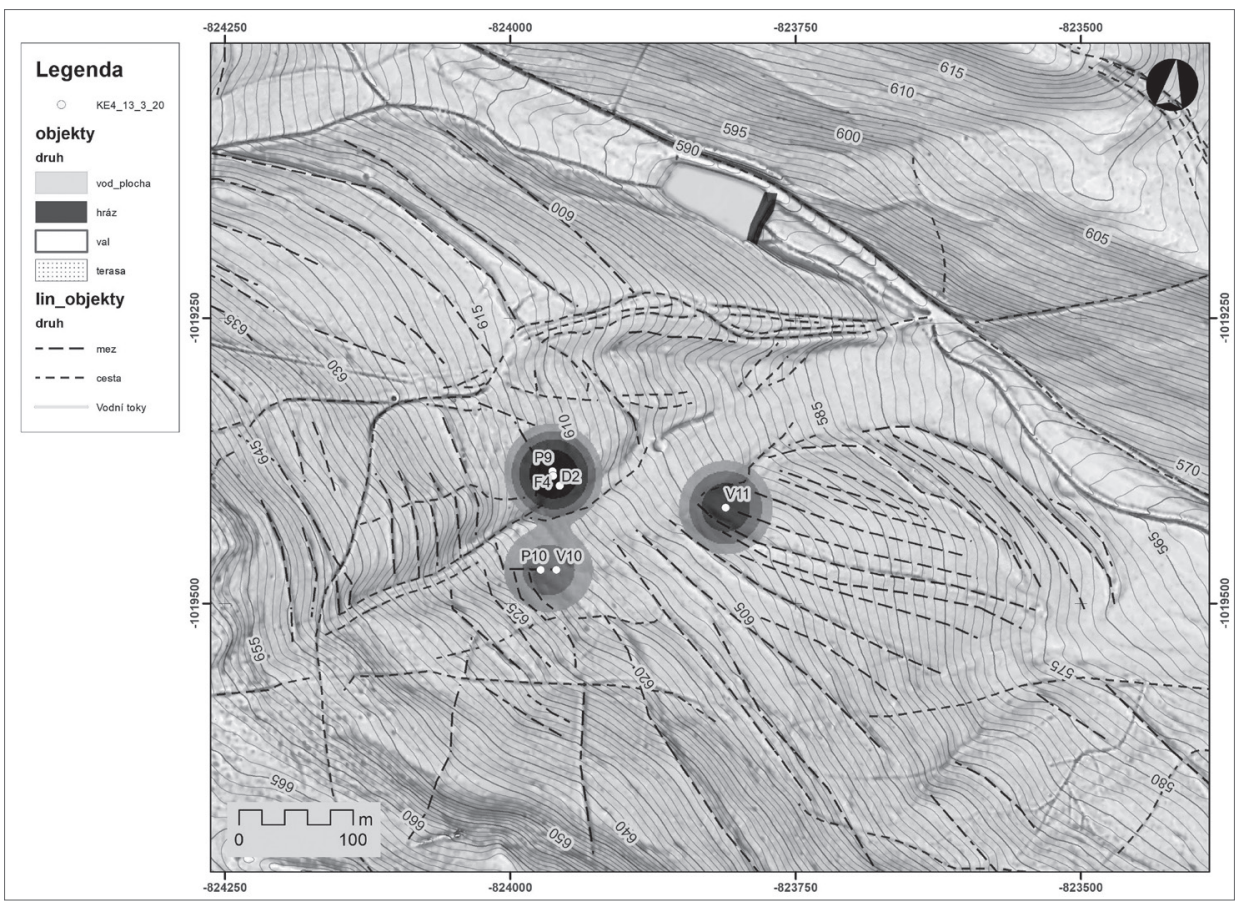

Obr. 11. Plán lokality ZSV Ořkov vytvořený z dat digitálního modelu reliéfu a terénní prospekce. Koncentrická orientace mezních pásů a nalezené fragmenty vrcholně a pozdně středověké keramiky napovídají existenci zaniklé středověké vesnice. Patrné jsou rovněž úvozy několika komunikací přetínající lokalitu od východu k západu. Autor F. Prekop, 28. 3. 2019.

Abb. 11. Anhand der Daten des digitalen Reliefmodells erstellter Plan der mittelalterlichen Dorfwüstung Ořkov und Geländeprospektion. Die konzentrische Orientierung der Grenzstreifen und die entdeckten hoch- und spätmittelalterlichen Keramikfragmente deuten auf die Existenz einer mittelalterlichen Dorfwüstung hin. Erkennbar sind auch die Hohlwege von einigen die Fundstelle von Ost nach West durchneidenden Verkehrswegen. Autor F. Prekop, 28. 3. 2019. 

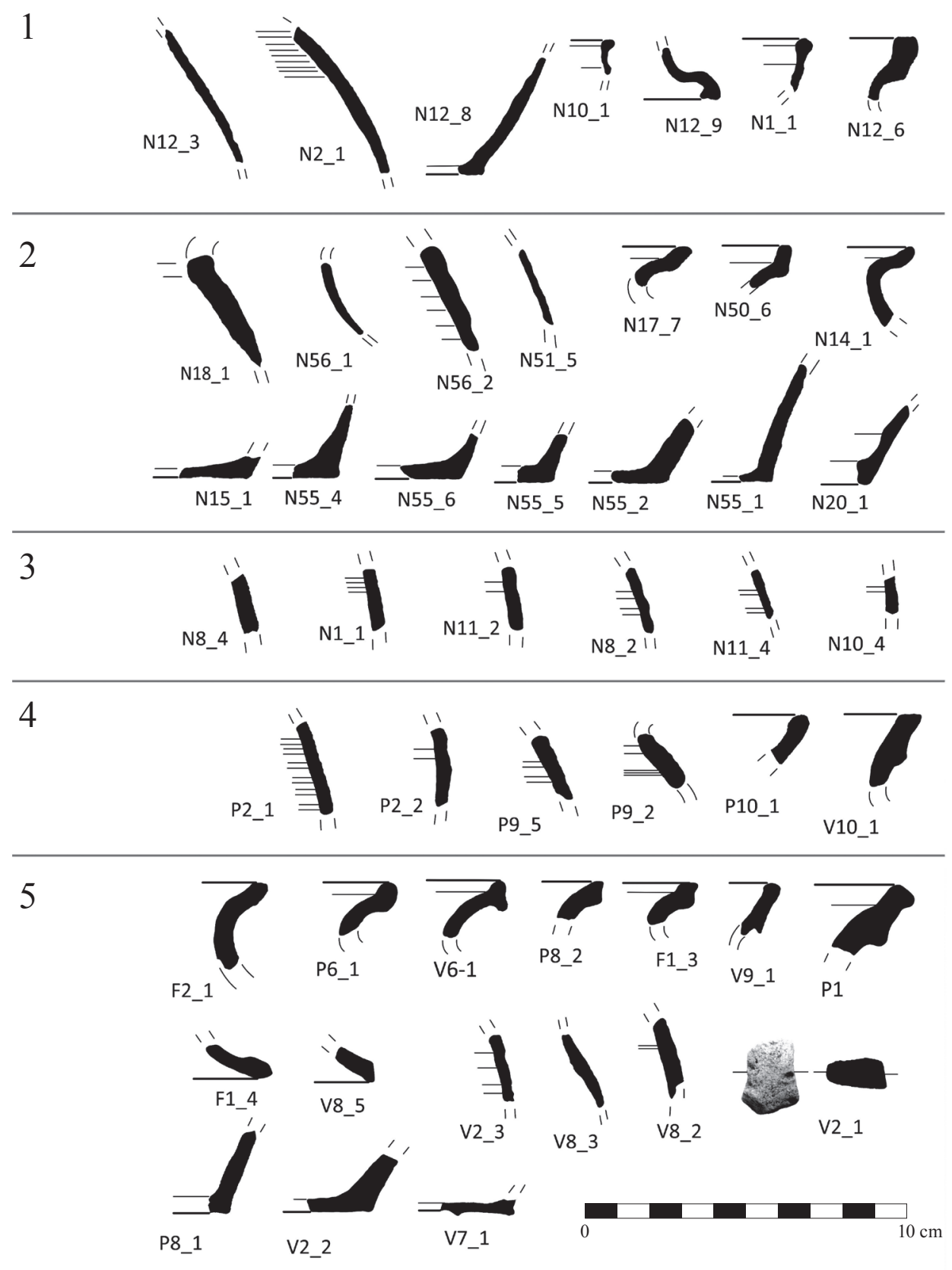

Obr. 12. Výběr získaných movitých nálezů z lokalit. 1 - Ledviny; 2 - Na pile; 3 - Doupovské Mezilesí; 4 - Ořkov; 5 - Valeč u Hradiště. Nálezy zpracované př́strojem LAP, uloženov NPÚ, ú. o. p. v Lokti. Autor F. Prekop, 28. 3. 2019.

Abb. 12. Auswahl an entdeckten beweglichen Funden von den Fundstellen. 1 - Ledviny; 2 - Na pile; 3 - Doupovské Mezilesí; 4 - Ořkov; 5 - Valeč u Hradiště. Die Funde wurden mit einem LAP-Gerät bearbeitet, aufbewahrt im Nationalen Denkmalamt, Gebietsfacharbeitsstelle Loket. Autor F. Prekop, 28. 3. 2019. 
V tomto př́ípadě je možné přiřadit lokalizované vsi název, a to Ořkov. Dodnes se dochoval jako pojmenování blízké hájovny. Ořkov se objevuje v písemných pramenech v 15. století. V závěti místního nižšího šlechtice Diviše z Křečova z roku 1424 je uveden pouze les Ořkov (DD 15, fol. 314; AČ 36, 659-660 č. 102; AČ 3, 496-497 č. 236). O něco později, v 50. letech 15. století, v rámci sporu o dědictví po pánech z Křečova uvádí žlutický měštan Jiřík Vachtýř, jeden ze svědků, že „,když jest spuštěno, že na tom les porostl“ čili po zpustošení vsi její areál zarostl lesem. Ves tedy v této době již neexistovala a její zánik je s velkou pravděpodobností možné spojit s kř́žzovou výpravou v roce 1421 (za informace děkujeme PhDr. Janu Marešovi, Ph.D., ze Státního okresního archivu Louny).

\subsection{ZSV na Mlýneckém potoce (k. ú. Valeč u Hradiště)}

V prameništi Mlýnského potoka, na počátku táhlého údolí, jsme prokázali přítomnost další, dosud poslední zaniklé středověké osady. Úzce prostorově souvisí s dnes udržovaným rybníkem (obr. 13). Lokalita je vzdálená přibližně $3 \mathrm{~km}$ severozápadním směrem od obce Valeč a $1,5 \mathrm{~km}$ a západním směrem od výše uvedené zaniklé vsi Ořkova (4). Prostor návsi zaujímá úpatí východního svahu vrchu Pilíŕ (762,7 m n. m.) v rozmezí 674-701 m n. m. Plužina vsi je orientovaná ve směru vrstevnic vrchu a je dobře patrná jak v severním, tak v jižním směru. Z digitálního modelu terénu i přímo v terénu lze dobře rozpoznat výrazné úvozy po intenzivně využívané komunikaci, která vedla při jižním okraji návsi a přecházela přímo po hrázi dnes obnoveného rybníka. Můžeme

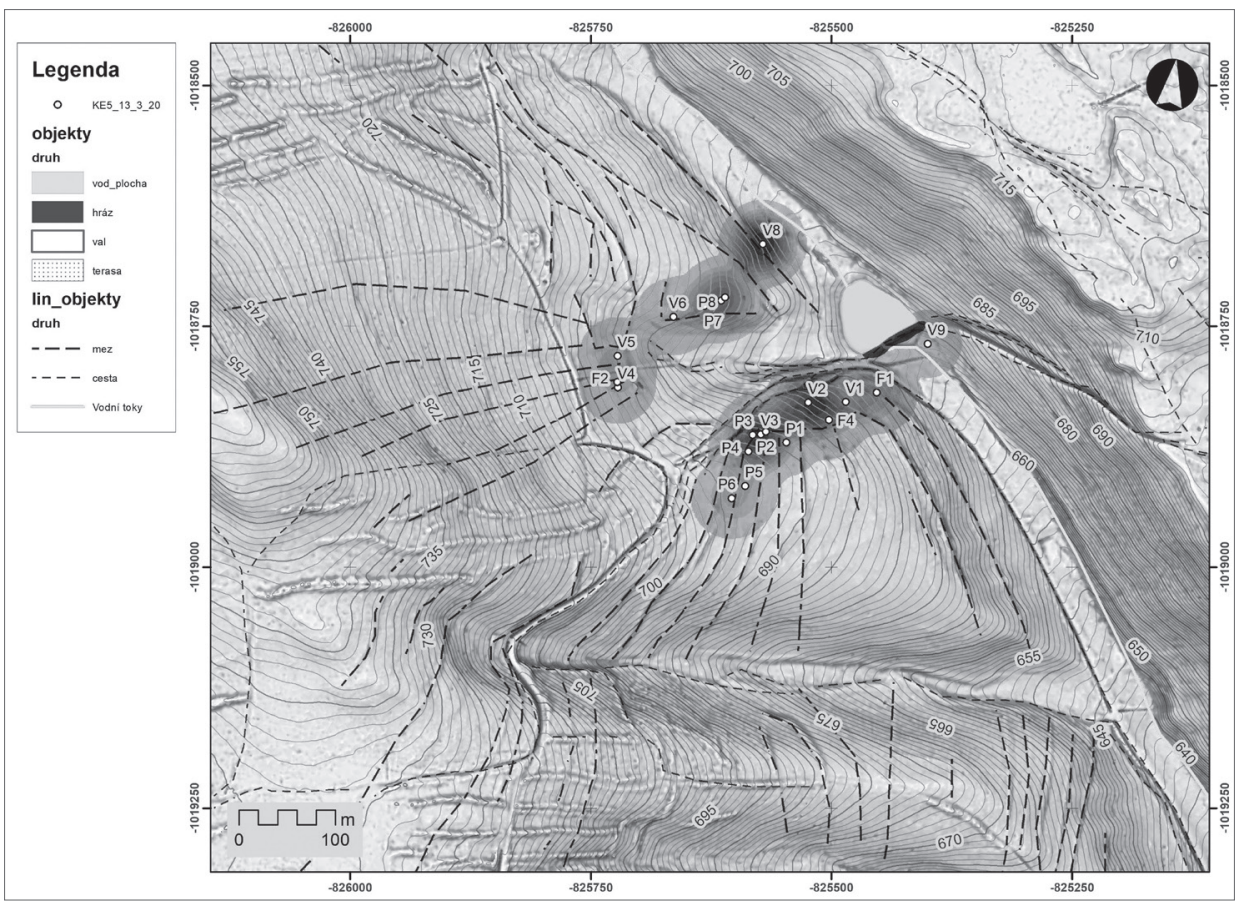

Obr. 13. Plán lokality ZSV Valeč u Hradiště vytvořený z dat digitálního modelu reliéfu a terénní prospekce. Velmi dobře jsou patrné relikty mezních pásů i navazující komunikace od východu. Ta dále fixuje polohu hráze obnoveného rybníka. V severní části jádra vsi je rozpoznatelných několik usedlostí. Poloha V9 označuje místo zaniklého mlýna. Autor F. Prekop, 28. 3. 2019.

Abb. 13. Anhand der Daten des digitalen Reliefmodells erstellter Plan der Fundstelle der mittelalterlichen Dorfwüstung Valeč u Hradiště und Geländeprospektion. Sehr gut erkennbar sind die Greinzstreifenrelikte und der von Osten anschließende Verkehrsweg. Dieser fixiert ferner die Lage des Damms des erneuerten Teichs. Im nördlichen Teil des Dorfkerns sind mehrere Anwesen erkennbar. Die Lage V9 bezeichnet die Stelle einer verschwundenen Mühle. Autor F. Prekop, 28. 3. 2019. 
ji pozorovat ještě ve stoupání na hřeben vrchu Jedliny a následném klesání do sousedního údolí Vrbického potoka. Pod hrází našeho rybníka jsou patrné stopy po náhonu a místu, kde stával mlýn. Je zajímavé, že první, obdobně jako druhé vojenské mapování a císařské otisky stabilního katastru rybník nezobrazují, ale sledovanou komunikaci vedoucí po jeho hrázi ano.

Terénní revize lokality proběhla 13 . března 2020 a přinesla soubor keramiky z jižního, západního i severního okraje zaniklé návsi. Celkem bylo získáno 47 keramických fragmentů (obr. 12:5). Několik fragmentů středověké keramiky pochází také z plochy zaniklého mlýna pod rybniční hrází (obr. 13, poloha V9). Z technologického hlediska jasně dominuje skupina šedobílé produkce s prŕměsí slídy i dalších příměsí $(35 \mathrm{ks})$. Našli jsme ale také několik reprezentantů redukční šedivé nebo slídnaté keramiky. Vyniká z nich fragment třmenového ucha z polohy V2, světle šedobílého nástřepí (obr. 12:5, V2_1). Během terénního průzkumu se podařilo identifikovat nejen pozůstatky po jednotlivých stavebních parcelách, ale na rozdíl od ostatních lokalit dokonce i několik objektů spojitelných s relikty usedlostí.

Dle literatury a II. vojenského mapování se v těchto místech nacházela v novověku hájenka (Binterová 2004, 26). Na digitálním modelu reliéfu je dobře patrná radiální plužina sbíhající k místu návsi, jejíž východní stranu uzavírá dodnes existující rybník. Relikty plužiny jsou pozorovatelné i ve vzdálenosti $1 \mathrm{~km}$ od pozůstatků vsi. Vzhledem k hustotě teras především na jižní straně vsi si v tomto př́ípadě nedovolujeme počet usedlostí odhadnout. Přiřazení názvu ke vsi je také velmi nejisté. A. Profous $(1947,249)$ uvádí s nejistou datací 1546 (1531?) zmínku ze zemských desk, ve kterých je ve výčtu majetků př́slušejících k Maštovu ves Cílkov. Pro naši potřebu je zajímavá především formulace „doluov k potoku k czylkowu a k mietikalowu“. Místo, kde stával do roku 1953 Mětikalov, je od námi identifikované vsi vzdáleno $4 \mathrm{~km}$. V tomto př́ípadě je samozřejmě nutný podrobný rozbor i dalších písemných pramenů, aby se domněnka o názvu nově nalezené vsi potvrdila, či nikoliv. Jen doplňme, že k roku 1542 je Cílkov uváděn jako pustý (DZ 1, H 2 a J 11, podle Profouse 1947, 249).

\section{Nevalidovaná pozorování}

Vzhledem k nastíněným okolnostem výzkumu evidujeme další pozorování, která nebylo doposud možné terénním průzkumem validovat, ale dle našich zkušeností lze existenci dalších vsí v těchto polohách již dnes považovat za průkaznou.

\subsection{ZSV pod vrchem Č́haná (k. ú. Podbořanský Rohozec a býv. Jeseň)}

Opět v prostoru aktivního újezdu Hradiště, 1 km jižně od existující obce Bukovina rozeznáváme relikty další středověké vsi. Rozprostírají se na severovýchodním svahu vrchu Č́́haná, $3 \mathrm{~km}$ západně od Podbořanského Rohozce, k jehož katastru dnes zčásti př́isluší (obr. 14). Na digitálním modelu reliéfu je možné rozpoznat dvě různé skupiny reliktů plužiny. Většinu svahu Č́íhané pokrývá terasování v pravidelných rozestupech, které kopíruje vrstevnice vrchu. Přibližně ve středu teras, v místě mělkého údolí s prameništěm se nacházela samotná nejspíše dvouřadá ves, na niž navazovala záhumenicová lánová plužina. Na ni kolmo navazuje druhá část plužiny dosahující až samotného hřebene ve výšce $740 \mathrm{~m}$ n. m. Jednalo se nejspíše o poměrně velkou ves. Budeme-li předpokládat, že jednotlivé terasy představují parcely usedlostí, musíme uvažovat o zhruba šestnácti usedlostech. Bohužel se zatím nepodařilo vsi přiřadit jméno, ač jich z písemných pramenů vztahujících se $\mathrm{k}$ bezprostřednímu okolí známe několik. Z roku 1424 pochází již výše zmíněná závět' Diviše z Křečova, drobného feudálního sídla, vzdáleného 4 km východně, která je soupisem majetku náležejícího tomuto nižšímu šlechtici (DD 15, fol. 314; AČ 36, 659-660 č. 102; AČ 3, 496-497 č. 236). Mimo lokality dosud existující jsou zde zmíněny vsi Olší, Budiš a Podolssy. Budiš lze poměrně s jistotou spojit s další zaniklou vsí, která se rozprostírala zhruba v polovině vzdálenosti mezi námi identifikovanou vsí a Podbořanským Rohozcem (Peksa 2014, 45-55). Vzhledem ke geomorfologickému uspořádání krajiny a k bezprostřední blízkosti majetků pánů 


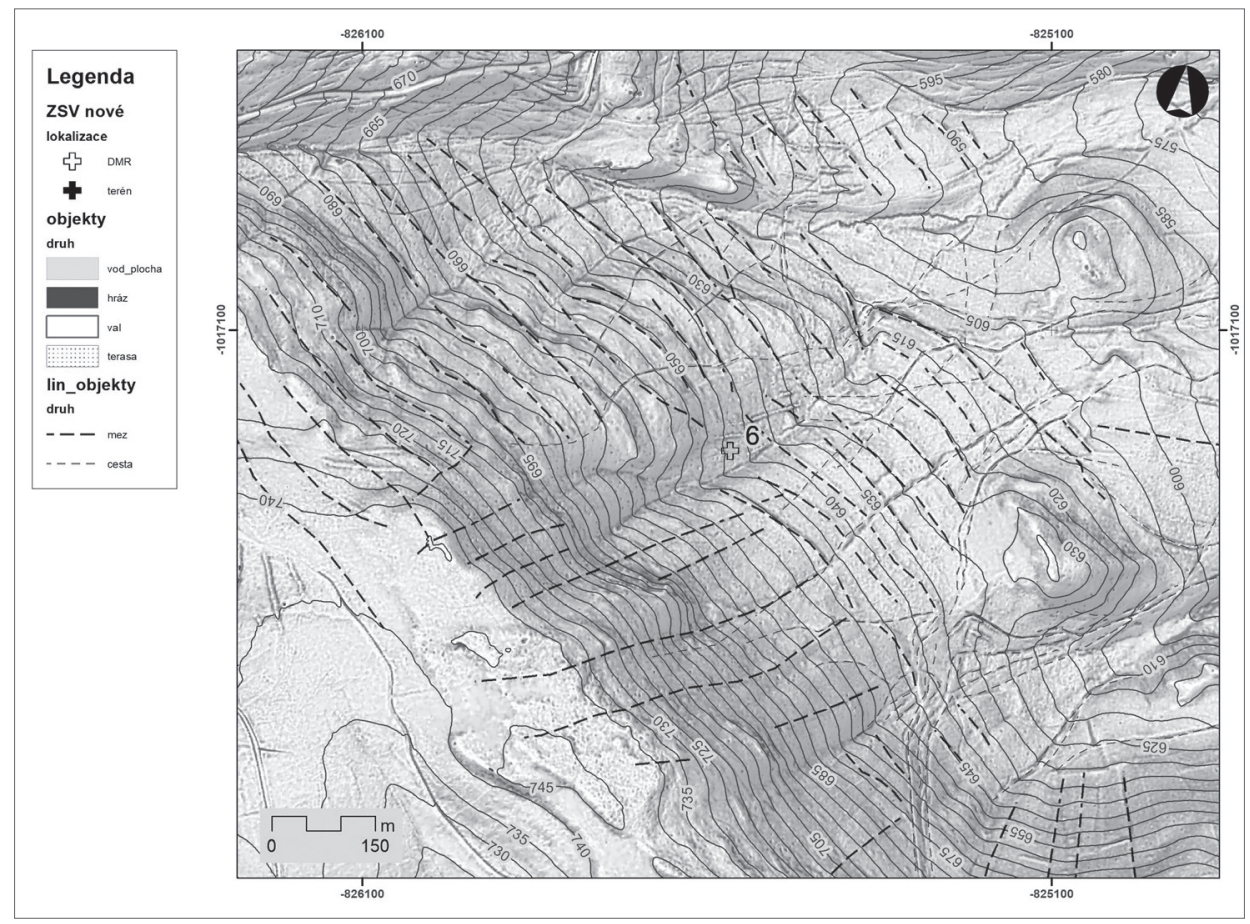

Obr. 14. Plán lokality ZSV pod vrchem Číhaná, která doposud nebyla podrobena terénní revizi. Sbíhající se linie mezních pásů jasně ukazují, kde se rozprostírá jádro zaniklé osady.

Abb. 14. Plan der Fundstelle der mittelalterlichen Dorfwüstung unterhalb des Hügels Číhaná, die bisher noch keiner Geländerevision unterzogen wurde. Die zusammenlaufenden Grenzstreifenlinien zeigen deutlich, wo sich der Kern der Siedlungswüstung erstreckt.

z Křečova předpokládáme, že námi nalezená ves do tohoto celku náležela, a tedy že se jedná o jednu ze dvou zbylých lokalit z Divišovy závěti. Ani jednu z nich však neznáme z žádného dalšího písemného pramene.

\subsection{ZSV Leskov (býv. k. ú. Konice a Tureč)}

Relikty zaniklé vsi se nacházejí také přibližně $2 \mathrm{~km}$ jižně od Turče a 1,8 km západně od osady Konice (obr. 15). Plužina této lokality je markantnější v její jižní polovině. Mezní pásy se k jihu a západu mírně rozbíhají a plužinu tak můžeme označit za radiální. Ves nejspíše návesního půdorysu se nacházela v pramenné pánvi. Tušit zde můžeme maximálně deset usedlostí. V oblasti, na severním svahu Konického vrchu pozorujeme také relikty dalšího drobného opevněného sídla, a to ca 560 m východním směrem od identifikované návsi. Vzhledem ke vzdálenosti i orientaci ji však s vesnicí nespojujeme. Objektem se budeme zabývat v budoucnosti. Přriřazení názvu k této vsi vedlo bádání T. Velímského o tzv. Maštovském újezdu (Velímský 1998, 69-80). Tento poměrně raný kolonizační záměr rodu Milhosticů byl uskutečněn již kolem poloviny 12. století a několik lokalit uvedených ve výčtu tohoto majetku zapsaného k roku 1196 (CDB I, 319-320 č. 355) se dosud nepodařilo v terénu identifikovat (ke kolonizaci této části Doupovských hor také Peksa 2017, 116-129). K újezdu, přesněji majetku Maštov (predium Mastowa nomine) patřilo trhové sídliště Pátek s vesnicemi: Maštov, Mladějov, Chotěbudice, Hunschan (patrně Němčany), Konice, Elscowe (zaniklá ves Leskov), Tureč, Minowe (zaniklá ves), Trmová, Vlsthene (snad Oleška), Telcov, Bluwaschowe (zaniklá ves), Hluboká, Szmilowa (zaniklá ves), Žebletín a dva 


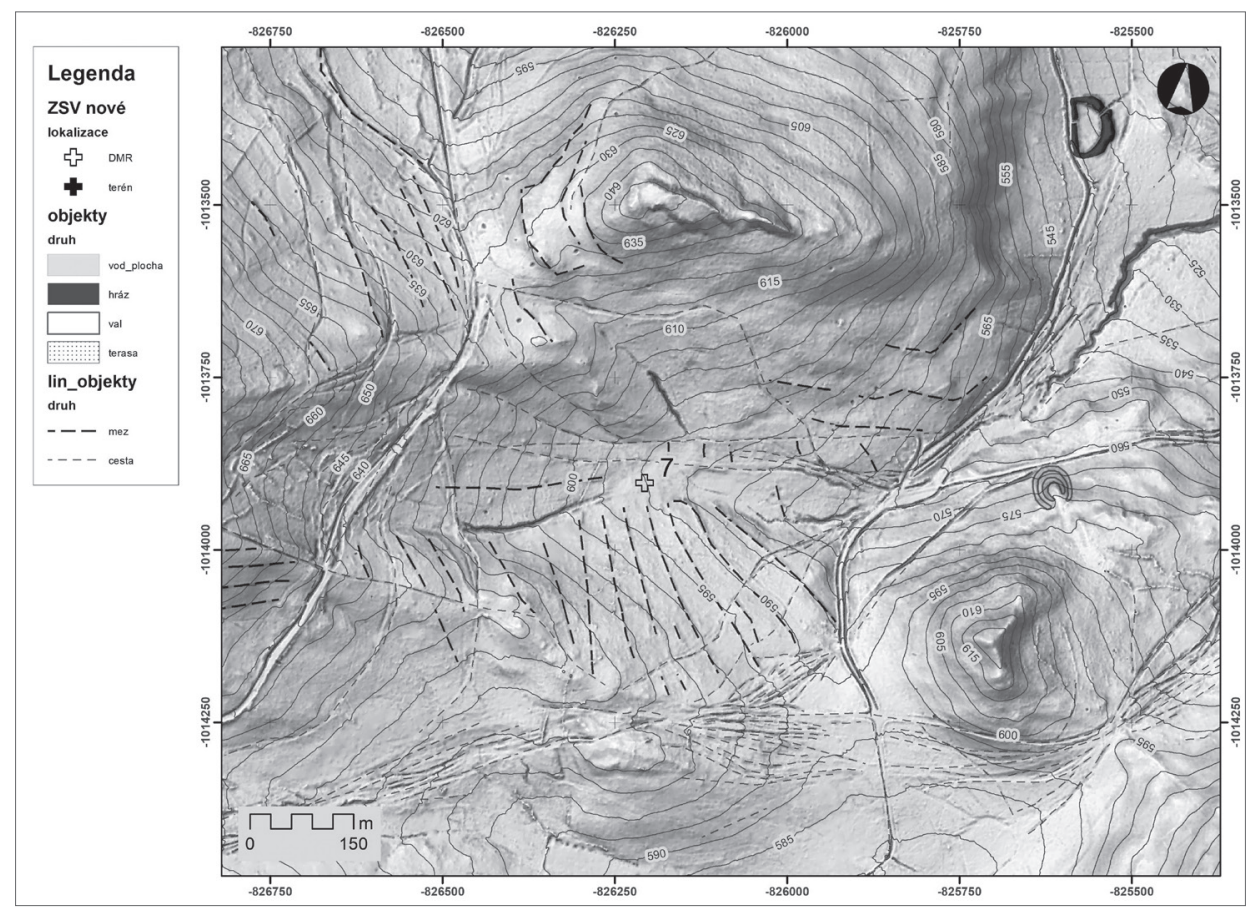

Obr. 15. Plán lokality ZSV Leskov, která doposud nebyla podrobena terénní revizi. Sbíhající se linie mezních pásů jasně ukazují, kde se rozprostírá jádro zaniklé osady. Okolí lokality je bohaté na relikty zaniklých komunikací. Východně od jádra vsi se nachází relikty dalšího, neznámého opevněného sídla, které nemusí s vesnicí souviset. Autor F. Prekop, 24. 9. 2020.

Abb. 15. Plan der Fundstelle der mittelalterlichen Dorfwüstung Leskov, die bisher noch keiner Geländerevision unterzogen wurde. Die zusammenlaufenden Grenzstreifenlinien zeiden deutlich, wo sich der Kern der Siedlungswüstung erstreckt. Die Umgebung der Fundstelle ist reich an Relikten verschwundener Verkehrswege. Östlich vom Dorfkern befinden sich Relikte einer weiteren unbekannten befestigten Siedlung, die mit dem Dorf in keinem Zusammenhang stehen muss. Autor F. Prekop, 24. 9. 2020.

dvory v Chrášt’anech a Třebčicích. Výčet vsí uvádíme především z jednoho důvodu, a to predikce T. Velimského (1998, 70), který ves Elscowe podle názvu kladl k pramenům potoka Lesky. A digitální model reliéfu opravdu nedaleko Konice odhalil výše popsanou zaniklou vesnici. Její radiální (klínová) plužina je zároveň nápadně podobná plužině sousední Konice. Je tak více než pravděpodobné, že nově objevená ves je ztotožnitelná s Elscowe čili Leskovem náležejícím do maštovského majetku.

\subsection{ZSV Hossagrün na Pstružném potoce (býv. k. ú. Jirov a Doupovské Mezilesí)}

Jde o dosud neznámou zaniklou středověkou ves v plochém údolí na severovýchodních svazích mezi vrchy U Tokaniště (pův. Klemel; 836 m n. m.) a Nad Ovčárnou (873 m n. m.). Zachycená plužina byla indikována díky liniím mezních stupňů stoupajících od soutoku Pstružného potoka (pův. Forellenbach, Forellen Bach, Zinn Bach) s pravostranným bezejmenným (?) přítokem od 717-857 m n. m., v celkové délce $1200 \mathrm{~m}$. Mezní stupně jsou patrné při obou březích, do vzdálenosti ca 750 metrů severně a 950 m jižně od potoka. V severovýchodní části plužiny nad soutokem potoků jsou dosud částečně obhospodařované louky a recentní rybníček, stejně tak v jihozápadní části plužiny. Při levém břehu potoka lze rozpoznat několik svahových odřezů, s velkou pravděpodobností domovních parcel. V horní části při potoce se nachází drobné tvrziště, o vnitřním rozměru ca $10 \times 15 \mathrm{~m}$, ze tří stran obkroužené mělkým př́ikopem a ze čtvrté strany vymezené potokem. Vnitřní dvoudílná část je plochá beze stop zástavby. Od jihu bylo tvrziště chráněno 
nízkým valem, po severním probíhala př́istupová cesta. Dispozičně se jedná o dlouhou lesní lánovou ves s lineární plužinou, patrně jednořadou, severovýchodní expozice (obr. 16). Majitelem pozemků v západní části ZSV bylo panství Kysibl (na k. ú. Doupovské Mezilesí), ve východní části panství Doupov (na k. ú. Jírov). Třetím majitelem byl kostel v Zakšově, což může indikovat původní farní lán. Mapa stabilního katastru z roku 1842 označuje celý prostor pomístním jménem Oed = Pustina. Louka na severním konci ZSV je na II. vojenském mapování označena špatně čitelným názvem „Ho...agrün“. Zde stála nejpozději od roku 1842 až do 50. let budova, která by měla být hájovnou, již zmiňuje J. G. Sommer. Ten dokonce uvádí louku Hossagrün se stopami domů. Název Hossagrün je tak s velkou pravděpodobností původní pojmenování vsi, které by plně zapadalo do kolonizačních názvů vsí v okolí. Lokalita Hossagrün je uvedena také v Chronik des Kirchensprengel Reschwitz mezi zaniklými osadami, ale bohužel jej nezachycuje žádná soudobá listina.

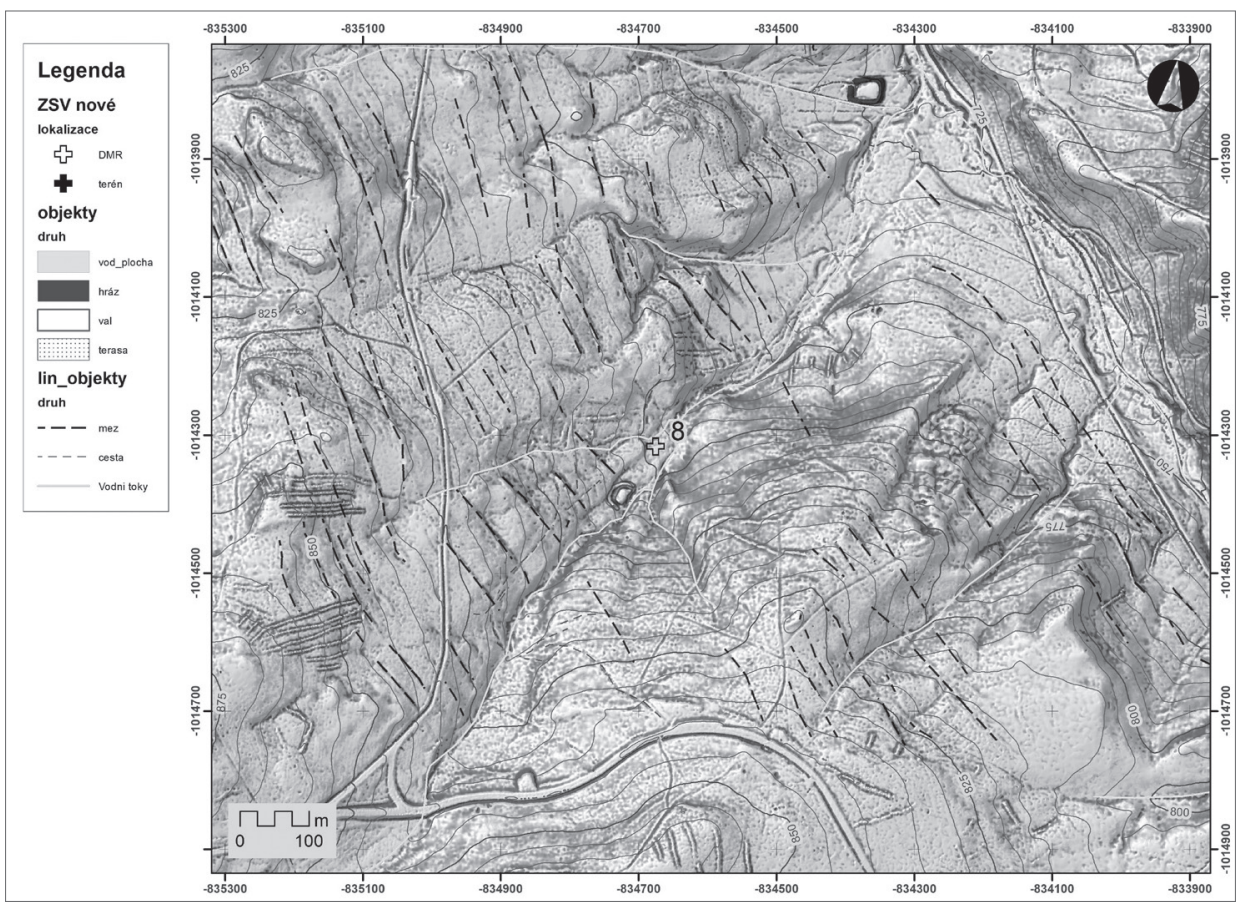

Obr. 16. Plán lokality ZSV na Pstružném potoce, kde jsme identifikovali také objekt tvrziště s dobře rozpoznatelným obvodovým př́ikopem, který navazuje na koryto Pstružného potoka. Na lokalitě doposud neproběhl terénní průzkum. Autor F. Prekop, 24. 9. 2020.

Abb. 16. Plan der Fundstelle der mittelalterlichen Dorfwüstung am Bach Pstružný potok, wo wir auch ein Objekt der Festungsstätte mit gut erkennbarem, an den Bach Pstružný potok angeschlossenem Ringgraben identifiziert haben. An der Fundstelle erfolgte bislang noch keine Geländeuntersuchung. Autor F. Prekop, 24. 9. 2020.

\subsection{ZSV Krinles, Krynles / Grünles, Grünlas (býv. k. ú. Zakšov)}

Relikty poslední představované, dosud neznámé zaniklé středověké vsi jsme rozpoznali v pramenné pánvi Pustého potoka (pův. Oedbach, Od-Bach, Grünles - Bach; Ascherloch - Bach), mezi jihovýchodními svahy Pustého zámku (Oedschlossberg; 932 m n. m.) a severním svahem Tmavého vrchu (Dunkels Berg, Oedberg; 857 m. n. m). Nachází se 3,3 km jihozápadně od 
Doupova, v jihovýchodním výběžku katastru Zakšova (obr. 17). Zaniklá plužina indikovaná na digitálním modelu reliéfu liniemi mezních stupňủ je patrná po obvodu pramenné pánve, s výjimkou prudkého severního svahu Tmavého vrchu, a stoupá od 758 do $880 \mathrm{~m} \mathrm{n}$. m.; stupně jsou patrné do vzdálenosti ca $700 \mathrm{~m}$ od ZSV. Ve spodní části jsou dosud obhospodařované louky, ostatní pokrývá les (k roku 1842 doloženo pomístní jméno Waldflur). Relikty se jeví jako pozůstatek zaniklé lesní lánové vsi s radiální plužinou a jižní expozicí; vlastní usedlosti, které ale nejsou patrné na digitálním modelu terénu, se mohly nacházet př̀i severním okraji pramenné pánve. Veškeré pozemky byly po zániku v majetku držitelů panství Doupov. Ves Krinles nebo, jak uvádí místopisná literatura, Krynles, Grünles či Grünlas je v písemných pramenech uvedena v roce 1518 ve výčtu majetků panství Doupov - s pustotinami krinles a gottes acker (zápis 1546, DZ 7, fol. J 22v-23). Spojení nalezené ZSV s lokalitou Krinles je možné především na základě pomístních názvů: leží v pramenné pánvi potoka Grünlesbach (1842k. ú. Doupov) neboli Grünles Bachl (1842 k. ú. Prachomety). Označení Grünlas se nachází na jedné mapě kadaňského okresu mezi Pustým zámkem a Prachomety (Langhans 1986, 3). V tomto místě doposud neproběhl terénní průzkum, který může výše uvedené do budoucna korigovat.

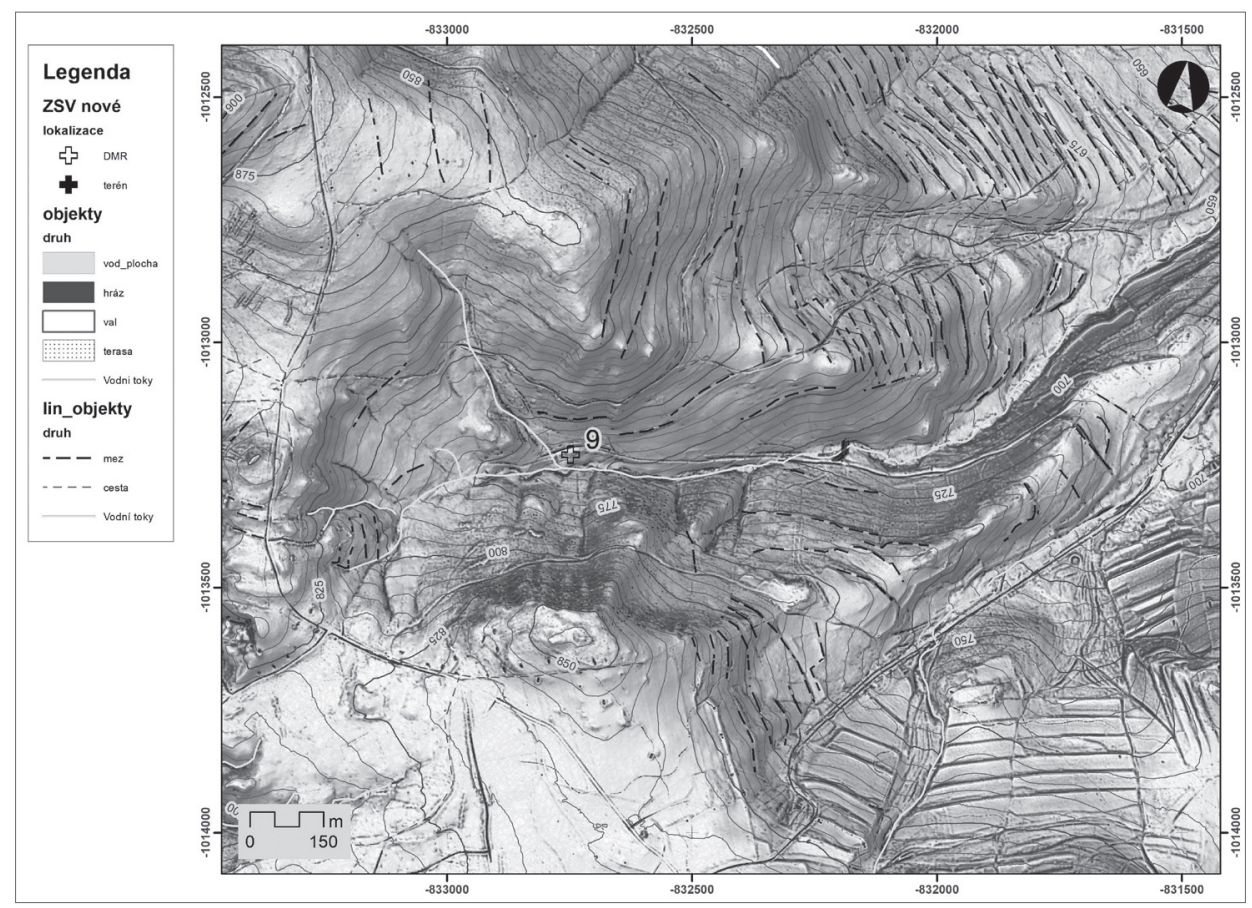

Obr. 17. Plán lokality se zaniklými mezními pásy na levobřeží Pustého potoka a relikty komunikací. Lokalita je ztotožnitelná s osadou Kringles dle historických pramenů. Na lokalitě neproběhl archeologický průzkum. Autor F. Prekop, 24. 9. 2020.

Abb. 17. Plan der Fundstelle mit verschwundenen Grenzstreifen am linken Ufer des Bachs Pustý potok und Verkehrswegerelikte. Die Fundstelle ist gemäß den historischen Quellen mit der Siedlung Kringles identifizierbar. Die Fundstelle wurde archäologisch nicht untersucht. Autor F. Prekop, 24. 9. 2020.

\section{Variabilita získané středověké keramiky}

Celkem bylo při terénních revizích získáno 320 různých keramických fragmentů zatím z pěti představených lokalit. Nejpočetnější je soubor 130 fragmentů z vesnice Na pile, pod Pustým 


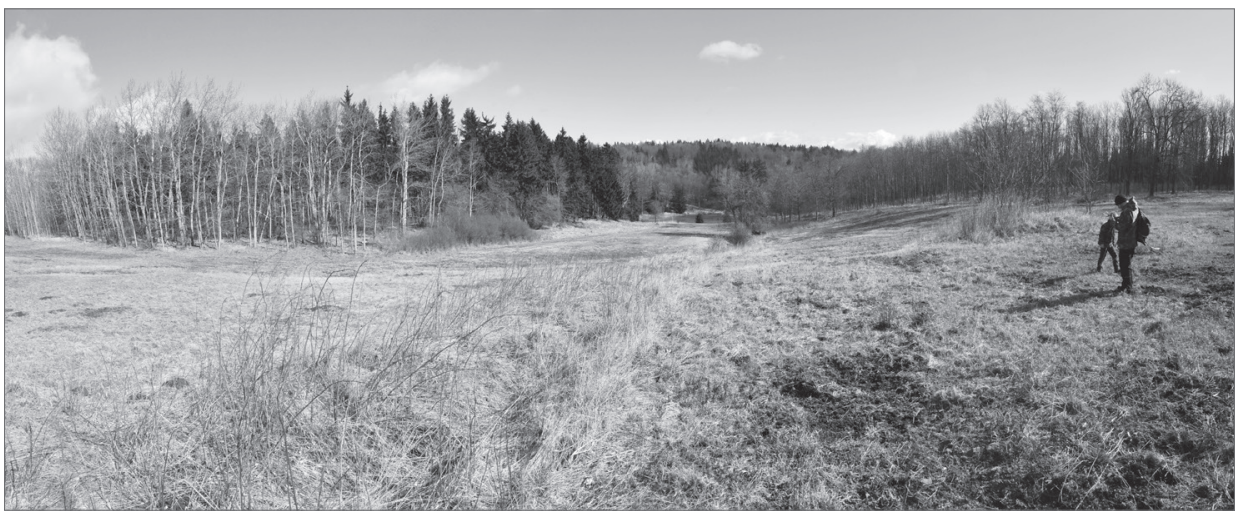

Obr. 18. Pohled na jádro lokality ZSV Valeč u Hradiště (5), pohled k východu. Foto F. Prekop, 13. 3. 2020.

Abb. 18. Blick auf den Kern der Fundstelle der mittelalterlichen Dorfwüstung Valeč u Hradiště (5), Blick von Osten. Foto F. Prekop, 13.3. 2020.

zámkem a soubor z Doupovského Mezilesí s 85 fragmenty. Zbylé tři soubory nedosahují 50 kusů. Snaha o dílčí členění a sledování prostorových distribucí nalezených fragmentů naráží na dva zkreslující faktory. Především je to nerovnoměrný počet nálezů a následně způsob jejich získání - povrchový sběr. Technologická produkce dosahuje ve všech lokalitách podobné zastoupení (obr. 19). Přestože jsme se snažili soustředit se na členění keramiky do hlavních keramických skupin (obr. 19, označené 1.0-5.0), evidovali jsme i jejich dílčí varianty (např. 1.1, 1.2). I zde platí, že klasifikace je značně subjektivní a při detailním členění je možné nalézt plynulé přechody mezi všemi definovanými množinami (Peksa 2019, 142).

Ve všech lokalitách jednoznačně dominuje keramická skupina šedobílého nástřepí, oxidačního výpalu s výraznou př́íměsí ostřiva, a to nejen slídy, která může být doplněná výzdobou rytých žlábků (obr. 19, ozn. 1.0). Specifickým motivem výzdoby je malovaná vodorovná červená linka, se kterou se setkáváme na několika dílčích variantách této keramické skupiny (obr. 12:5, V8_3). Ostatní způsoby výzdoby, jako jsou ryté hluboké či mělké žlábky nebo šroubovice, nejsou nijak specificky vázané na uvedenou technologickou skupinu. Její reprezentanti výrazně dominují v souborech Na pile (2) a ZSV na k. ú. Valeč u Hradiště (5). Zvlášt' jsme se zaměřili na dílčí variantu skupiny označené 1.2 , jež označuje fragmenty s okrovou barvou nástřepí, oxidačně pálené a malované červenou hlinkou. Její výskyt můžeme považovat za vzácný, ale prokázaný ve všech lokalitách, kromě polohy ZSV Valeč. Méně, ale přesto ve všech lokalitách zastoupenou je rovněž skupina tmavě šedivého nástřepí, redukčního výpalu s výraznou prríměsí slídy (ozn. 2.0). S ní jsme se hojně setkávali na všech lokalitách, nejvíce v obou početnějších souborech - ZSV Na pile a ZSV Doupovské Mezilesí. Velmi obdobně rozptýlenou skupinou je rovněž keramika šedivé barvy, redukčně pálená, bez výrazné př́íměsi slídy (3.0). Tato skupina je méně častá než předchozí dvě skupiny. Zaměřili jsme se ještě na jednu z dílčích variant, kterou považujeme za typickou pro oblast širšího území Karlovarska a dobře rozlišitelnou. Jedná se o skupinu redukčního výpalu se specifickou povrchovou úpravou vnějšího povrchu pomocí červenohnědé engoby (ozn. 3.2). Keramické těsto je relativně prosté ostřiva. Nejčastěji jsme se s ní setkali v nejbohatším souboru ZSV Na pile. Ojediněle pak i v ostatních lokalitách, s výjimkou ZSV Valeč. Tento způsob provedení keramiky, který z jiných lokalit relativně bezpečně spojujeme s obdobím druhé poloviny 14. století až první poloviny 15. století, je v oblastech Podbořanska velmi vzácný (Peksa 2019). Třídu keramiky 4.0 vysokého redukčního výpalu bez makroskopicky patrného ostřiva lze chápat jako nejmladší horizont keramiky středověké tradice. Zachytili jsme jej v nejpočetnějších souborech ZSV Na pile a ZSV Doupovské Mezilesí, obdobně jako již časně novověkou keramiku oxidačního výpalu s transparentní glazurou (5.0.). 
(1) Ledviny

(2) Na pile

(3) D. Mezilesí

(4) Ořkov

(5) Valeč
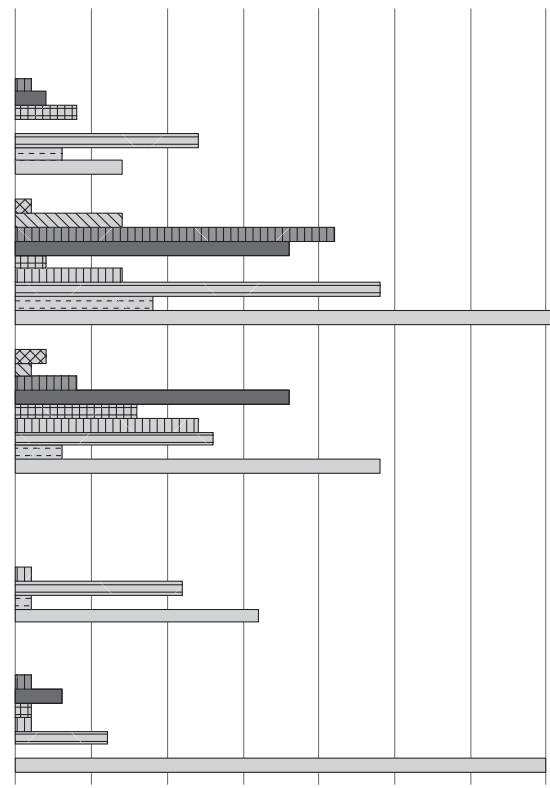

$\begin{array}{llllllll}0 & 5 & 10 & 15 & 20 & 25 & 30 & 35\end{array}$
冈 5.0 - oxidační, vysoký výpal, glazovaná

$\mathbb{\nabla} 4.0$ - redukční, vysoký výpal, modrošedá

(II) 3.2 - redukční výpal, s engobou

3.0 - redukční výpal, šedivá

四 2.4-oxidační výpal, okrová, výrazně slídnatá

(I) 2.1 - redukční výpal, výrazně slídnatá s engobou

目 2.0 -redukční výpal, výrazně slídnatá

园 1.2 - oxidační výpal, okrová, malovaná

1.0 - oxidační výpal, bílá s př́měsí, malovaná

Obr. 19. Rozložení jednotlivých keramických skupin na nalezených lokalitách. Je patrné, že z lokality Na pile pochází nejpočetnější soubor keramiky, který vykazuje i nejpestřejší technologické zastoupení. Autor F. Prekop, 24. 9. 2020.

Abb. 19. Verteilung der einzelnen Keramikklassen an den entdeckten Fundstellen. Man kann erkennen, dass der größte Keramikkomplex von der Fundstelle Na pile stammt und auch das technologisch bunteste Vorkommen aufweist. Autor F. Prekop, 24. 9. 2020.

\section{Závěr}

V předložené práci chceme především poukázat na značný archeologický potenciál území vojenského újezdu Hradiště v Doupovských horách. Rovněž zde představujeme prŕínos zvolené metody průzkumu krajiny, jež se opírá o systematické vyhodnocení digitálního modelu terénu a cílené terénní prospekce. Tímto způsobem lze přinášet pozitivní archeologická zjištění i z takto obtížně př́istupné krajiny. U veřejnosti zcela pochopitelně dominuje názor, že zřízení zdejšího vojenského újezdu je jedním z negativních následků druhé světové války nebo úmyslnou státní devastací kulturního dědictví vlastní země. Poukazujeme zde ale na méně patrný fakt, že jednorázové opuštění více než 65 sídel a všech běžných lidských aktivit na kompaktním územím se zcela radikální změnou užívání můžeme s odstupem téměř 70 let vnímat také jako unikátní archeologickou událost. Uchránění území před turbulentními zásahy člověka v druhé polovině 20. století, včetně individuálního stavebního boomu po roce 1989 právem z území Doupovských hor vytváří archeologickou rezervaci nemalého významu. Doupovské hory tak dnes nabízí komplexní pohled na hmotné pozůstatky „tradičního“ způsobu života, který se zde vedl od středověku do poloviny 20. století.

Představená zjištění je možné spojovat s dobou nejstarších etap stabilního osídlení, které bylo značně dynamické. Naše práce rozšiřuje seznam archeologických lokalit o zcela nové sídelní areály středověkých vsí doplněné o další objekty šlechtických sídel a samozřejmě jejich plužin. 


\section{Doupovsko - četnost technologických skupin}

1.0 - oxidační výpal, bílá s prríměsí, malovaná

1.2 - oxidační výpal, okrová, malovaná

2.0 - redukční výpal, výrazně slídnatá

2.1 - redukční výpal, výrazně slídnatá s engobou

2.4 - oxidační výpal, okrová, výrazně slídnatá

3.0 - redukční výpal, šedivá

3.2 - redukční výpal, s engobou

4.0 - redukční, vysoký výpal, modrošedá

5.0 - oxidační, vysoký výpal, glazovaná

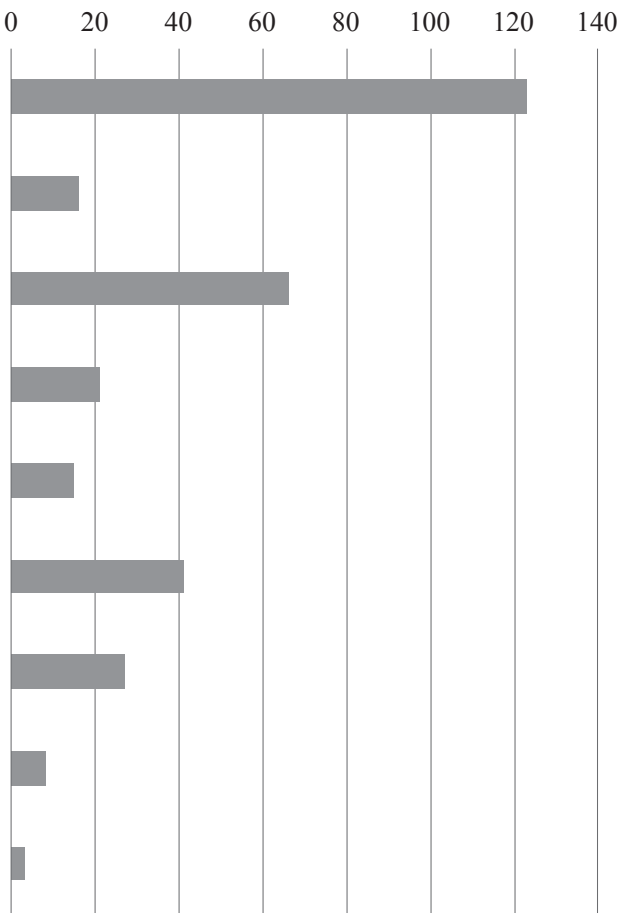

Obr. 20. Četnost výskytu jednotlivých zástupců keramických skupin z nalezených lokalit. Členění odpovídá hlavním druhům keramiky a jejich několika signifikantním podskupinám. Dominují fragmenty s bílým nástřepím $s$ výraznou příměsí nejen slídy (1.0) a redukěně pálená keramika s výraznou příměsí slídy (2.0). Autor F. Prekop, 24. 9. 2020.

Abb. 20. Vorkommenshäufigkeit der einzelnen Keramikklassenvertreter an den entdeckten Fundstellen. Die Gliederung entspricht den Hauptkeramikarten und einigen ihrer signifikanten Unterklassen. Es dominieren Fragmente mit weißer Engobe und deutlicher Beimischung nicht nur von Glimmer (1.0) und im Reduktionsbrand gebrannter Keramik mit deutlicher Glimmerbeimischung (2.0). Autor F. Prekop, 24. 9. 2020.

Předkládáme rovněž indicie $\mathrm{k}$ lokalizaci dalších zaniklých středověkých vesnic, které dosud nebyly podrobeny terénním průzkumům. Rozborem písemných pramenů jsme se pokusili o přiřazení správných názvů k objeveným vsím. U některých lokalit ale zůstává jejich pojmenování nejisté. Domníváme se, že u Doupovského Mezilesí jsme nalezli pozůstatky obce Bernardsgrün (3), pod vrchem Pustý zámek relikty vsí Vous/Wauss (2), Krinles (9) a Hossagrünn (8), nedaleko Mašt'ova pak ves Leskov (7). V blízkosti prameniště Vrbičského potoka se rozprostírala ves Ořkov a severně od Valče pravděpodobně osada Cílkov (5). Otazník zůstává u vsi s ojedinělou dvojicí tvrzišt', snad Litoltov (1), a také u vsi nedaleko Podbořanského Rohozce (6). Vznik i zánik většiny z nich spadá do vrcholného či pozdního středověku. Velkým omezením je bud' jejich úplná absence ve středověkých písemných pramenech, nebo až velmi pozdní zaznamenání. Především doba vzniku vesnic tak do budoucna zůstane úkolem pouze archeologie. Je třeba konstatovat, že co do množství zaniklých stř̌edověkých vsí na relativně malém prostoru můžeme dnes Doupovské hory bezesporu srovnávat s ikonickými oblastmi Černokostelecka či Drahanské vrchoviny.

Technologický rozbor nalezené stř̌edověké keramiky dokládá tranzitní charakter Doupovska, ve kterém se mísí keramická produkce typická jak pro oblast Podbořanska nebo Žatecka, tak 
pro širší oblasti Loketska, potažmo Karlovarska. Doupovské hory se nám tak jeví jako důležité přechodové území se specifickými přírodními podmínkami a hraniční polohou mezi tradičními sídelními oblastmi středního a horního Poohří. Svým řídkým osídlením se staly předmětem relativně rané kolonizace, a to hned $\mathrm{z}$ několika směrů, především z východního úpatí. Na základě písemných pramenů je jisté, že osidlování započalo již kolem poloviny 12 . století a plně se rozvinulo v následujícím 13. století. Sídelní sít pak byla do plné podoby doplňována i ve století čtrnáctém. Svou roli sehrála i důležitá komunikace - tzv. Královská cesta přecházející Doupovské hory východozápadním směrem. Iniciátory postupu osídlení byly především severozápadočeské kláštery a rod Hrabišiců.

První fáze zanikání vsí v Doupovských horách vyvolala křížová výprava v počátcích husitských válek, ač v pozadí nalezneme bezesporu kumulaci více problémů, které neumožnily obnovení jednotlivých sídel. Absence výskytu drahých kovů společně s relativně specifickými, ale úrodnými půdami vyvřelinového původu zabránila výraznější novověké industrializaci oblasti, která si proto zachovala svůj primární lesnicko-pastevecko-zemědělský charakter, a to v podstatě až do 20. století. Vojenské užívání považujeme za další ze specifik oblasti, která zde vytváŕí její nezaměnitelný charakter.

Př́spěvek vznikl v rámci dílčího cíle: „Terénní identifikace a dokumentace vybraných archeologických lokalit a opomíjených archeologických památek v krajině za pomoci standardních a nových dokumentačních metod“ výzkumné oblasti I. Archeologie financované z institucionální podpory Ministerstva kultury na dlouhodobý koncepční rozvoj (IP DKRVO) a výzkumného projektu Proměna středověkého venkovského kostela jako symbolu duchovní tradice a identity DG18P02OVV042, financovaného z Programu na podporu aplikovaného výzkumu a experimentálního vývoje národní a kulturní identity na léta 2016 až 2022 (NAKI II).

\section{Prameny}

CDB: Codex diplomaticus et epistolaris regni Bohemiae. T. I. (Friedrich, G., ed.). Pragae 1904-1907.

DD VII: Desky dvorské VII. První kniha půhonná z let 1383-1407. Liber citationum primus inde ab anno MCCCLXXXIII usque ad annum MCCCCVII. Praha 1929.

DD VIII: Desky dvorské VIII. Druhá kniha půhonná z let 1407-1530. Der zweite Ladungsquatern von 1407-1530. Praha 1944.

AČ 36: Archiv český. Díl 36. Třetí kniha provolací desk dvorských z let 1411-1448 (Friedrich, G., ed.). Praha 1941.

DZ: Národní archiv Praha, fond Desky zemské.

RT II: Reliquiae tabularum terrae Regni Bohemiae. T. II. (Emler, J., ed.). Praha 1872.

CIM II: Codex iuris minucipalis Regni Bohemiae. T. II. (Čelakovský, J., ed.). Praha 1895.

\section{Literatura}

BELCREDI, L., 2006: Bystřec. O založení, životě a zániku středověké vsi. Brno.

BERNAU, F., 1881: Album der Burgen und Schlösser im Königreiche Böhmen I. Saaz.

BINTEROVÁ, Z., 1998: Zaniklé obce Doupovska. V bývalém okrese Kadaň. Chomutov.

- 2004: Zaniklé obce Doupovska II. V bývalých okresech Karlovy Vary a Žlutice. Chomutov.

BOLINA, P.-KLIMEK, T.-CÍLEK, V., 2018: Staré cesty v krajině středních Čech. Praha.

DERNER, K., 2018: Stř̌edověké hornictví na Př́isečnicku v Krušných horách - Veröffentlichungen des Landesamt für Archäeologie Sachsen. Band 68. ArchaeoMontan 5. Dresden.

DVOŘÁK, R., 1884: Druhá výprava křižáků německých do Čech (1421), Sborník historický II, 360-366. 
FIALA, J., 2005: Historické cesty starého Loketska. Karlovy Vary.

GNIRS, A.-GNIRS, A., 1996: Topographie der historischen und kunstgeschichtlichen Denkmale in dem Bezirke Karlsbad. (Prag 1933). München.

GRADL, H., 1893: Geschichte des Egerlandes bis 1437. Praha.

HEREIT, P., 2000: Nejstarší osídlení Doupovska, Sborník západočeského muzea v Plzni 15, Řada historie, $117-175$.

HOFFMAN, V., 1996: Allerley kuryweil-Mittelalterliche und Frühneuzeitliche Spielzeugfunde aus Sachsen. In: Arbeit und Forschungsberichte zur Sächsischen Bodendenkmalpfliege. Band 38, 127-200. Dresden.

HRADECKÝ, P. a kol., 2016: Hradecký, P.-Rapprich, V.-Mlčoch, B.-Lojka, R.-Matějů, J., Geologie. In: Doupovské hory (Matějů, J.-Hradecký, P.-Melichar, V., edd.), 15-56. Praha.

KOMÁR, A., 1993: Vojenský újezd Hradiště, Sborník české geografické společnosti 2, 75-86.

KUBU゚, F., 1990: Druhá křížová výprava proti husitům roku 1421, Minulostí západočeského kraje 26, $113-121$.

LANGHANS, W., 1986: Jurau, Gerichtsbezirk Duppau, Kreis Kaaden, Reg.-Bezirk Eger. Kaadner Heimatsbrief, Nr. 433, Februar 1986, Kassel.

LOJKA, R., 2016: Sedimenty mladších prvohor. In: Doupovské hory (Matějů, J.-Hradecký, P.-Melichar, V., edd.), 19-21. Karlovy Vary.

MĚCHUROVÁ, Z., 2010: Středověký svět dětí a her v archeologických pramenech - Die mittelalterliche Welt der Kinder und Spiele in archäologischen Quellen, AH 35, 95-107.

NEUSTUPNÝ, E., 1986: Nástin archeologické metody, AR XXXVIII, 525-548.

PACHNER, J.-SEDLÁČEK, H., 2019: Staré cesty v krajině Doupovských hor. Chomutov.

PALACKÝ, F., 1873: Urkundlich Beiträge zur Geschichte des Hussitenkrieges. Praha.

PEKSA, V., 2014: Středověké osídlení Podbořanska. Nepublikovaná bakalářská práce, ulož. na FF UK, Praha.

- 2017: Středověké osídlení středního Poohří. Nepublikovaná diplomová práce, ulož. na FF UK, Praha.

- 2019: Středověká keramika středního Poohří. In: Archeologie severozápadních Čech 1. Sborník k poctě Milanu Zápotockému (Trefný, M., ed.), 139-199. Ústí nad Labem.

PLESL, E.-HÁJEK, L.-MARTÍNEK, J., 1983: Pravěk Karlovarska a Sokolovska a katalog archeologických sbírek muzeí v Karlových Varech a Sokolově. Karlovy Vary.

PREKOP, F., 2017: Záchranný archeologický výzkum při stavbě: Okružní pěšina hradu Bečov n. T. Nálezová zpráva, ulož. v Archivu NPÚ, ú. o. p. v Lokti.

PREKOP, F.-KRIŠTUF, P.-PEKSA, V., 2018: Výšinný ohrazený areál na Kružínském vrchu, k. ú. Skytaly, AZČ $13,17-26$.

PREKOP, F. a kol., 2017: Prekop, F.-Krištuf, P.-Peksa, V.-Eigner, J.-Kočár, P., Nové doklady osídlení výšinných poloh na Karlovarsku - polykulturní lokality Orlík a Šibeniční vrch u obce Valeč v Čechách, AZČ 12, 41-66.

PROFOUS, A., 1947: Místní jména v Čechách. Jejich vznik, původní význam a změny. Díl I. Praha.

- 1949: Místní jména v Čechách. Jejich vznik, původní význam a změny. Díl II. Praha.

- 1951: Místní jména v Čechách. Jejich vznik, původní význam a změny. Díl III. Praha.

SEDLÁČEK, A., 1998: Hrady, zámky a tvrze Království českého. Díl třináctý. Praha.

SKLENÁŘ, K., 1999: Hromové klíny a hrnce trpaslíků. Praha.

ROUBÍK, F., 1959: Soupis a mapa zaniklých osad v Čechách. Praha.

SOMMER, J., 1847: Das Königreich Böhmen. Elbogener Kreis. Praha.

ŠMAHEL, F., 1996: Husitská revoluce 3. Kronika válečných let. Praha.

VELÍMSKÝ, T., 1998: Trans montes, ad fontes! (Přes hory, k pramenům!). Most.

- 2002: Hrabišici. Páni z Rýzmburka. Praha.

\section{Internetové zdroje}

STÁTNÍ ARCHEOLOGICKÝ SEZNAM. Dostupné z: https://geoportal.npu.cz/ISAD/, cit. 1. 12. 2020.

ARCHEOLOGICKÁ MAPA ČESKÉ REPUBLIKY. Dostupné z: http://www.archeologickamapa.cz/, cit. 1. 12. 2020. 
PRVNÍ VOJENSKÉ MAPOVÁNÍ. Dostupné z: http://oldmaps.geolab.cz/, cit. 1. 12. 2020.

DRUHÉ VOJENSKÉ MAPOVÁNÍ. Dostupné z: https://ags.cuzk.cz/archiv/, cit. 1. 12. 2020.

CÍSAŘSKÉ OTISKY STABILNÍHO KATASTRU. Dostupné z: https://ags.cuzk.cz/archiv/, cit. 1. 12. 2020.

\section{Zusammenfassung}

\section{Neue Feststellungen von der Untersuchung der verbotenen Landschaft im Duppauer Gebirge - mittelalterliche Dorfwüstungen}

Die vorliegende Arbeit stellt neu lokalisierte mittelalterliche Dorfwüstungen im Raum des aktiven Truppenübungsplatzes Hradiště im Bezirk Karlsbad vor, der bis zum Jahr 2016 der größte Truppenübungsplatz der Tschechischen Republik war. Jegliche Fundstellen konnten primär anhand eines digitalen Reliefmodells identifiziert werden, das wir anhand von Daten einer Laserhöhenmessung ausgearbeitet haben. In der vorliegenden Arbeit wird auf diese Weise unter anderem eine Methode vorgestellt, wie man auch einen sehr schwierig zugänglichen Teil einer Landschaft archäologisch effizient untersuchen kann. Fünf von zehn Fundstellen konnten bereits durch eine archäologische Oberflächenuntersuchung bestätigt werden, bei der auch Komplexe beweglicher Funde, vor allem Küchenkeramik des Hoch- und Spätmittelalters entdeckt wurden. In direktem Bezug zu den Sitzen wurde das Vorhandensein von kleinen befestigten Herrensitzen bestätigt. Im Falle der Fundstelle Ledviny haben wir sogar zwei dieser Objekte identifiziert. Anhand einer Analyse der schriftlichen Quellen haben wir versucht, den entdeckten Dörfern die richtigen Namen zuzuordnen. Bei einigen Fundstellen bleibt ihre Benennung jedoch unsicher. Der Charakter der mittelalterlichen Besiedelung des Duppauer Gebirges (Doupovské hory) erscheint uns insgesamt als Peripherie einiger traditioneller Siedlungsgebiete von der Grenze des mittleren und oberen Egertals, denen die einzelnen Sitze eigentumsmäßig angehört haben. Der zentrale Charakter der Verwaltung der Stadt Duppau (Doupov) trat erst in den jüngeren Perioden der Gebietsverwaltung in Erscheinung. Seine Rolle in der Landschaft hat auch der homogene geologische Untergrund eruptiven Ursprungs gespielt. Dieser Umstand gewährleistete zwar auch in höheren Lagen als in denen der umliegenden Gebiete einen guten landwirtschaftlichen Bodenertrag, andererseits bereitete dort - wegen der inhomogenen Gliederung der Landschaft - das Fehlen jedweden Mineralreichtums Komplikationen.

Der vorliegende Beitrag entstand im Rahmen des Teilziels: „Geländeidentifikation und -dokumentation von ausgewählten archäologischen Fundorten und übersehenen archäologischen Denkmälern in der Landschaft mithilfe von standardmäßigen und neuen Dokumentationsmehthoden“ Forschungsgebiet I. Archäologie, finanziert durch die institutionelle Föderung des Kulturministeriums für langfristige konzeptuelle Entwicklung (IP DKRV) und das Forschungsprojekt Wandel der mittelalterlichen Dorfkirche als Symbol für geistliche Tradition und Identität DG18P02OVV042, das vom Programm zur Förderung angewandter Forschung und experimenteller Entwicklung nationaler und kultureller Identität finanziert wird.

Mgr. Filip Prekop, Národní památkový ústav, územní odborné pracoviště v Lokti, Kostelní 81, 35733 Loket, Česká republika,prekop.filip@npu.cz

PhDr. Petr Krištuf, Ph.D., Katedra archeologie Fakulty filozofické Západočeské univerzity v Plzni, Sedláčkova 15, 30614 Plzeň, Česká republika,pkristuf@kar.zcu

PhDr. Vojtěch Peksa, Ústav archeologické památkové péče severozápadních Čech, v. v. i., Jana Žižky 835/9, 43401 Most, Česká republika,peksa@uappmost.cz 
Jiří Crkal, Ústav archeologické památkové péče severozápadních Čech, v. v. i., Jana Žižky 835/9, 43401 Most, Česká republika,jiri.crkal@seznam.cz

David Černý, Merklín 23, 36234 Merklín, Česká republika, merkelsgrun@seznam.cz 
